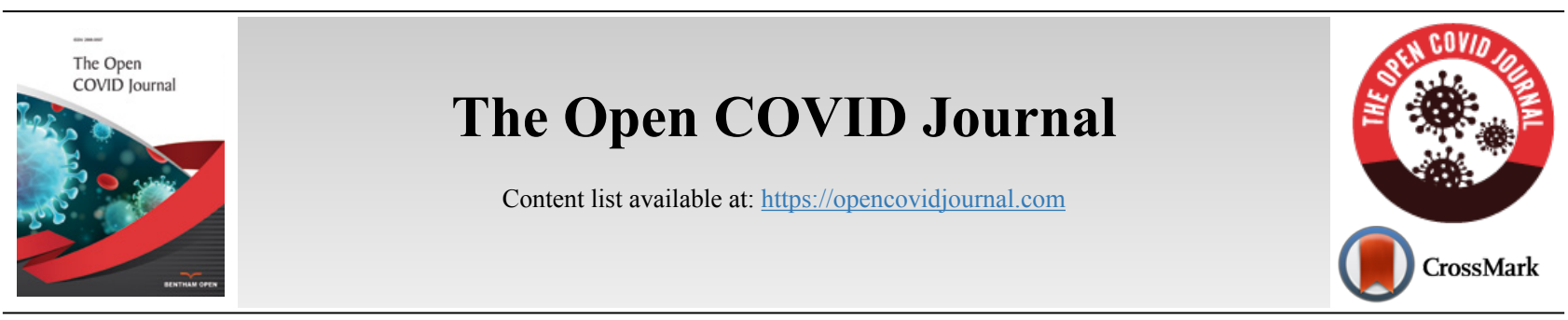

REVIEW ARTICLE

\title{
Genomic Variation and Treatment Strategies of COVID-19: A Descriptive Review
}

\author{
Satyabrata Kundu ${ }^{1}$ and Shamsher Singh ${ }^{1, *}$ \\ ${ }^{1}$ Department of Pharmacology, ISF College of Pharmacy, Moga, Punjab, India
}

\begin{abstract}
:
Coronavirus disease 2019 (COVID-19) was spread across China and affected more than 180 countries worldwide to date. SARS-CoV-2 is a beta coronavirus that shows genomic similarity with bat coronaviruses. The intermediate source in human viral transmission is caused by dromedary camels for MERS-CoV and civet cats for SARS-CoV. Transmission of the virus from human-to-human is achieved through close contact with infected persons. The genome of the coronavirus consists of four structural proteins, including Spike (S), Membrane (M), Envelop (E), and Nucleocapsid (N) proteins. These structural proteins are encoded within the genome 3 ' end. The spike protein is responsible for virus attachment to the host cell surface receptors (angiotensin converting enzyme-2 receptor), resulting in fusion and subsequently cell damage. The $\mathrm{N}$ protein, after binding, causes RNA genomic changes. The accessory proteins present in SARS-CoV open read frames (ORFs) are very similar to COVID 19. The COVID-19 infection triggered a number of deaths and even now affecting a number of confirmed cases. Coronavirus patients are characterized by pneumonia, cytokine storms, weakened lymphocytes, lymphocytopenia, and respiratory failure. However, the lack of antiviral vaccines permits emergency clinical trials since January 2020. Recently, several anti-viral drugs are being repositioned and restructured as part of an immediate investigation. In this review, we discussed the genomic sequence of SARS-CoV-2, its different features and current therapeutic strategies to combat this serious condition.
\end{abstract}

Keywords: Coronavirus disease (COVID-19), Open Reading Frame (ORF), SARS-CoV-2, Virus challenges, Genomic variations, Clinical trials.

\begin{tabular}{|l|l|c|c|}
\hline Article History & Received: December 3, 2020 & Revised: January 18, 2021 & Accepted: January 19, 2021 \\
\hline
\end{tabular}

\section{INTRODUCTION}

Coronaviruses are in the family of coronaviridae. Coronavirus is a positive-sense single-stranded RNA (+ssRNA) with a much smaller size (65-125 $\mathrm{nm}$ in diameter). Coronaviruses are primarily subdivided into four classes, such as alpha, beta, gamma, and delta. Alpha and beta mainly infect people, while birds and mammals are infected with gamma and delta. Epidemics such as SARS-CoV in 2002-2003, Middle East Respiratory Syndrome of Coronavirus (MERS-CoV) in 2012, Acute Lung Injuries (ALI), and Acute Respiratory Distress Syndrome (ARDS) in 2012 have occurred in the last two decades [1]. China informed World Health Organization (WHO) in December 2019 about one of the unfamiliar diseases that took over 1800 lives in the first 50 days. The SARS-CoV-2 situation was confirmed by the International Committee on Virus Taxonomy (ICTV) [2]. SARS-CoV (2002-2003) infected 8422 individuals with 916 deaths, with $11 \%$ mortality rate [3]. On the other side, COVID-19 infects individuals with a seven percent mortality rate [4]. The analysis clearly shows

\footnotetext{
* Address correspondence to this author at Department of Pharmacology, ISF College of Pharmacy, Moga-142001, Punjab, India; Tel: +91-9779980588;

E-mail: shamshersinghbajwa@gmail.com
}

that the SARS-CoV-2 transmission rate is higher than SARS$\mathrm{CoV}$ and could be due to the spike(S) genetic mutation in the receptor domain of SARS-CoV-2. Chinese people had SARS and coronavirus confirmed in 2003 [5]. In patients with acute severe respiratory syndrome, pneumonia has occurred, and bone marrow cells can be infected, which leads to thrombocytopenia [6]. In 2012, the Saudi Arabia population was diagnosed with a group of coronaviruses known as Middle East Respiratory Syndrome (MERS-CoV). Patients with MERS$\mathrm{CoV}$ have experienced breathing disorders and kidney failure, as well. The recent SARS-CoV-2 outbreak has mild (80\%) to moderate $(20 \%)$ symptoms associated. The virus was identified as a novel coronavirus following a sequence-based analysis [7].

Details of viral pneumonia in infected patients were reported by the Chinese National Health Commission in January 2020 [8]. The virus transmission is caused by close contact with infected individuals, exposure to respiratory droplets, or the use of fomites. Given the minimal size of the respiratory droplets, they can travel quickly to an individual's lung by inhalation $[9,10]$. SARS-CoV-2 is similar in the phylogenetic sequence to SARS-CoV (79\%). SARS-CoV-2, SARS-CoV, and MERS-CoV biological features, as illustrated in Table $\mathbf{1 .}$ 
Table 1. Characterization of several features of SARS-CoV, MERS-CoV, and SARS-CoV-2.

\begin{tabular}{|c|c|c|c|c|}
\hline Characteristics & SARS-CoV & MERS-CoV & SARS-CoV-2 & References \\
\hline Outbreak & November 2002 & November 2012 & December 2019 & [11] \\
\hline Place & Guangdong, China & Saudi Arabia & Wuhan, China & {$[12,13]$} \\
\hline Primary reservoir & Bat, palm civet & Camel, bat & Bat & [14-16] \\
\hline Countries affected & 26 & 27 & Over 180 & [17-19] \\
\hline Receptor involve & ACE2 receptor & ACE2 receptor & DPP4 receptor & {$[20,21]$} \\
\hline Diagnosis & $\begin{array}{l}\text { RT-PCR, } \\
\text { rRT-PCR }\end{array}$ & RT-LAMP & $\begin{array}{l}\text { RT-PCR, } \\
\text { rRT-PCR }\end{array}$ & {$[22-24]$} \\
\hline
\end{tabular}

\section{CORONAVIRUS TRANSMISSION}

The pandemic with an unknown etiology arose from the Chinese seafood industry for the first time. The source and transmission of the virus must be determined to develop potential therapeutics. As Bat-CoV is 96.2 percent, similar to human SARS-COV-2, the bat is reported to be the primary coronavirus reservoir. The person who has a history of visiting or contacting the infected area is reported to be infected with the virus. The National Health Commission of China notified the chances of transmission between health workers. One reason for transmission was the consumption of infected animals and direct contact with primary or secondary reservoirs. Asymptomatic infection can occur in persons with lower immune responses. The viral load found in asymptomatic patients has been found to be similar to the virus transmission capacity of symptomatic patients $[25,26]$. Fig. (1) shows the transmission of coronaviruses from animals to humans.

\section{THE ENTRY MECHANISM OF THE HUMAN CORONAVIRUS}

The four types of structural glycoproteins are contained in coronaviruses, including Spike (S), Membrane (M), Nucleocapsid (N), and Envelope (E). Spike glycoprotein is primarily responsible for interacting and entering the host organism. The Open-Reading Frame1 (ORF1) encodes structural proteins for all coronaviruses with unique genes [27]. Cryo-electron tomography has been shown to form an extra interior layer of the transmembrane protein in the carboxy region, thickening the viral membrane [28]. Coronaviruses are ingested according to various enzymes such as trypsin-like human Proteases in airways, cathepsins, and serine-2 Transmembrane proteases (TMPRSS2) responsible for the removal of glycoprotein. Spike (S) protein is composed of S1 and S2 subunits, responsible primarily for the binding to the host receptor and viral cell membrane fusion by forming a six-helical bundle, respectively $[29,30]$. The dipeptidyl peptidase-4 (DPP-4) was reported to act as a receptor for MERS-CoV, while ACE2 was shown to be the entry receptor for SARS-CoV [21].

The SARS-CoV-2 coronavirus structure is made up of glycoprotein fusion with implicit RNA polymerase, papain-like protease, helicase, and accessory proteins. SARS-CoV-2 spiked protein is mainly attached with van der waals forces to the receptor-binding domain [31 - 33].

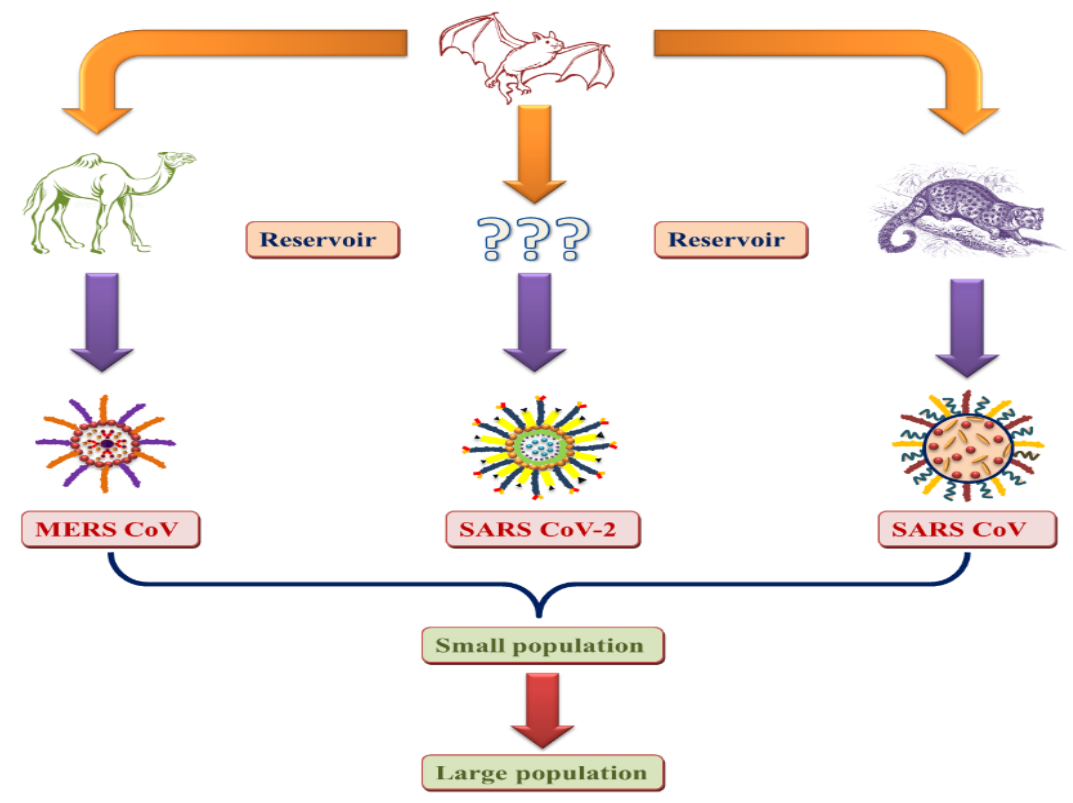

Fig. (1). Schematic diagram showing how coronavirus is transmitted from animal source to human population. 

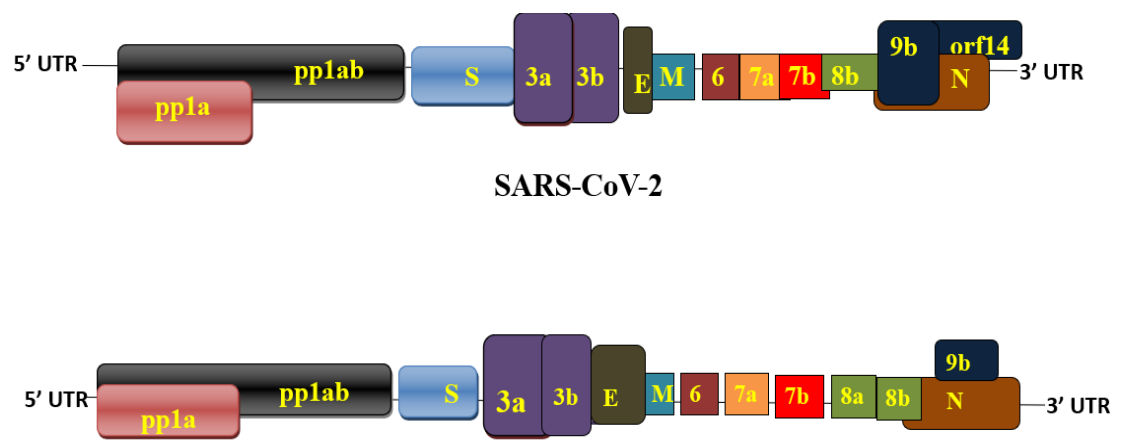

SARS-CoV

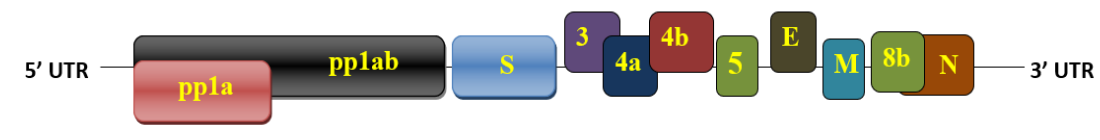

MERS-CoV

Fig. (2). Schematic diagram showing the genomic variation of SARS-CoV-2, SARS- CoV, and MERS-CoV.

The glutamine residue 394 in SARS-CoV-2 ReceptorBinding Domain (RBD), which has a structural resemblance to 479 residues in SARS-CoV, can be identified by the essential lysine 31 on the human ACE2 receptor [34]. SARS-CoV-2 recognizes human ACE2 more prominently than SARS-CoV, responsible to increase the transmission rates from person to person [35]. N501T mutation in SARS-CoV-2 spike protein increased binding affinity to angiotensin-converting enzyme 2 , causing pathogenic divergence from SARS-CoV [8].

\section{GENOMIC VARIATIONS}

Coronavirus genome consists of approximately 2600032000 bases (SARS-CoV 29,712; SARS-Cov-2 30,000; MERS-CoV 30,119) including variability in Open Reading Frames (ORFs) [36]. The genomic sequence of SARS-CoV-2 was registered in the NCBI genome database (NC_045512.2), approximately $29.9 \mathrm{~kb}$ in size [37]. The genomic analysis of SARS-CoV-2 showed a similarity of $96.3 \%, 89 \%$ and $82 \%$ with bat $\mathrm{CoV}$, SARS-like $\mathrm{CoV}$, and SARS-CoV, respectively [38]. The genome of SARS-Cov-2 has 11 protein-coding genes with 12 expressed proteins. Basically, open reading frames are designed as replicase and protease (1a-1b), and major structural proteins are arranged from $5^{\prime}$ to $3^{\prime}$ order and preferred for drug targets [39]. The retrieved translated sequence of SARS-CoV-2 from GenBank showed that it encodes about 7096 long polyprotein residues with various structural and non-structural proteins [40]. The orf1ab gene in SARS-CoV-2 encodes pp1ab protein and 15 non-structural proteins (nsps), whereas the orfla gene codes for ppla protein and 10 non-structural proteins. The $15 \mathrm{nsps}$ were categorised from nsp1 to nsp10 and nsp12 to nsp16. The orflab and orfla genes are located at the $5^{\prime}$ end and encode pp1ab and pp1a, respectively, and the 3 ' end of the genome contains four structural glycoproteins (S, E, M, N) and eight accessory proteins (3a, 3b, p6, 7a,7b 8b, 9b, and orf14) [31]. SARS-CoV has some differences in accessory proteins (3a, 3b, 6, 7a, 7b, 8a, 8b, and 9b) [41]. The accessory proteins help in virus transmission, initiates pathological events and produce pro-inflammatory cytokines and activate interferon signaling [38]. The genetic makeup of SARS-CoV- showed there are 380 amino acid changes from different protein to the proteins of recent SARS-CoV-2. For example, accessory proteins, S protein and $\mathrm{N}$ protein have 348,27 and 5 amino acid changes, respectively [42]. The coronavirus phylogenetic tree revealed a structural similarity between SARS-CoV-2 and SARS-CoV [11, 43]. The amino acid sequence of SARS$\mathrm{CoV}-2$ is quite similar to SARS-CoV, but there are differences in $8 \mathrm{a}$ and $8 \mathrm{~b}$ proteins [31]. For example, 8a protein present is in SARS-CoV but not in SARS-CoV-2; 8 b protein consists of 84 amino acids in SARS-CoV, whereas amino acids in SARS$\mathrm{CoV}$; $3 \mathrm{~b}$ protein is composed of amino acids in SARS-CoV but only 22 amino acids in SARS-CoV-2 [44].

MERS-CoV has a structural resemblance with SARS-CoV2. Genetically, MERS-CoV is composed of $5^{\prime}$ cap structure, a poly (A) tail at $3^{\prime}$ end, the rep gene consists of 16 nsps (nsp1nsp16). At the $3^{\prime}$ end, it consists of structural proteins (S, E, M, $\mathrm{N})$ as well as 5 accessory proteins $(3,4 \mathrm{a}, 4 \mathrm{~b}, 5,8)[36,45]$. The accessory SARS-CoV-2, SARS-CoV- and MERS-CoV proteins have a certain heterogeneity, shown in Fig. (2) for their genomic variability.

\section{TREATMENT STRATEGY}

At the moment, coronavirus cannot be fully cured by any therapy. The primary use of antibiotics and anti-viral medicines is to relieve loads of viral RNA [46]. The combination of lopinavir and ritonavir showed clinical effectiveness against SARS-CoV but not against 2019-nCoV [47]. Remdesivir blocked, in particular 2019-nCoV replication combined with chloroquine or immune interferon $[8,48]$. The results for newly-infected patients were successfully proved by isolated blood plasma from clinically treated COVID-19 patients. 


\subsection{Anti-viral Drugs}

There are no successful anti-viral agents that can fight against COVID-19. Lopinavir is a protease inhibitor in only one in in vitro and pre-clinical studies. Anti-viral drug remdesivir has been shown to be effective against Ebola [49]. It shows efficacy against RNA viruses and can combat against RNA-dependent RNA-polymerase(RdRp) [50]. Lists of recent clinical trials of anti-viral drugs in COVID-19 patients are shown in Table 2.

Table 2. Clinical trials of Antiviral drugs in COVID-19 patients.

\begin{tabular}{|c|c|c|c|c|c|c|c|}
\hline $\begin{array}{c}\text { Identification } \\
\text { Number }\end{array}$ & Public Title & Group 1 & Group 2 & Group 3 & Group 4 & $\begin{array}{l}\text { Primary } \\
\text { Outcome }\end{array}$ & $\begin{array}{l}\text { Primary } \\
\text { Sponsor }\end{array}$ \\
\hline ChiCTR2000031734 & \begin{tabular}{|c|} 
Evaluation \\
Danorevir sodium \\
tablets combined \\
with ritonavir in the \\
treatment of novel \\
Coronavirus \\
Pneumonia \\
(COVID-19): a \\
randomized, open- \\
label, controlled \\
trial
\end{tabular} & $\begin{array}{c}\text { Experimental group- } \\
\text { Danorevir sodium } \\
\text { tablets,/ritonavir } \\
\text { oral (40 patients) }\end{array}$ & - & - & - & \begin{tabular}{|c} 
Rate of \\
composite \\
adverse \\
outcomes: $\mathrm{SpO}_{2}$, \\
$\mathrm{PaO}_{2} / \mathrm{FiO}_{2}$, \\
respiratory rate
\end{tabular} & $\begin{array}{c}\text { Huoshenshan } \\
\text { Hospital }\end{array}$ \\
\hline ChiCTR2000030472 & \begin{tabular}{|c|} 
An open and \\
controlled clinical \\
study to evaluate \\
the efficacy and \\
safety of Ganovo \\
combined with \\
ritonavir in the \\
treatment of novel \\
coronavirus \\
pneumonia \\
(COVID-19)
\end{tabular} & \begin{tabular}{|} 
Experimental group- \\
Ganovo/ ritonavir \\
oral+conventional \\
treatment (10 \\
patients)
\end{tabular} & $\begin{array}{l}\text { Control group- } \\
\text { Conventional } \\
\text { treatment (10 } \\
\text { patients) }\end{array}$ & - & - & \begin{tabular}{|c|} 
Rate of \\
composite \\
adverse \\
outcomes: $\mathrm{SpO}_{2}$, \\
$\mathrm{PaO}_{2} / \mathrm{FiO}_{2}$, and \\
respiratory rate
\end{tabular} & $\begin{array}{l}\text { Shenyang } \\
\text { Sixth } \\
\text { People's } \\
\text { Hospital }\end{array}$ \\
\hline ChiCTR2000030218 & \begin{tabular}{|c|} 
Study of Lopinavir \\
/ Ritonavir Tablets \\
(Trade Name: \\
Kelizhi) Combined \\
with Xiyanping \\
Injection for Novel \\
Coronavirus \\
Pneumonia \\
(COVID-19)
\end{tabular} & $\begin{array}{l}\text { Experimental group- } \\
\text { Lopinavir/ritonavir } \\
\text { tablets combined } \\
\text { with Xiyanping } \\
\text { injection ( } 30 \\
\text { patients) }\end{array}$ & $\begin{array}{l}\text { Control group- } \\
\text { Keep ritonavir/ } \\
\text { ritonavir treatment } \\
(30 \text { patients })\end{array}$ & \begin{tabular}{|c|}
$\begin{array}{c}\text { Experimental } \\
\text { group- }\end{array}$ \\
Lopinavir/ritonavir \\
tablets combined \\
with Xiyanping \\
injection \\
(20 patients)
\end{tabular} & - & $\begin{array}{l}\text { Pneumonia } \\
\text { Severity Index } \\
\text { (PSI) score }\end{array}$ & $\begin{array}{c}\text { Fifth } \\
\text { People's } \\
\text { Hospital of } \\
\text { Ganzhou }\end{array}$ \\
\hline ChiCTR2000030113 & \begin{tabular}{|c|} 
Randomized \\
controlled trial for \\
safety and efficacy \\
of Favipiravir in \\
the treatment of \\
novel coronavirus \\
pneumonia \\
(COVID-19) with \\
poorly responsive \\
ritonavir/ritonavir
\end{tabular} & $\begin{array}{c}\text { Control group-Keep } \\
\text { ritonavir/ritonavir } \\
\text { treatment (15 } \\
\text { patients) }\end{array}$ & $\begin{array}{l}\text { Experimental } \\
\text { group-Favipiravir } \\
\text { (15 patients) }\end{array}$ & - & - & $\begin{array}{c}\text { Blood routine } \\
\text { tests, Liver } \\
\text { function } \\
\text { examination, } \\
\text { Renal function } \\
\text { examination, } \\
\text { Blood gas } \\
\text { analysis, Chest } \\
\text { CT Examination }\end{array}$ & $\begin{array}{l}\text { The Third } \\
\text { People's } \\
\text { Hospital of } \\
\text { Shenzhen }\end{array}$ \\
\hline ChiCTR2000029603 & \begin{tabular}{|c|} 
A Randomized, \\
Open-Label, Multi- \\
Centre Clinical \\
Trial Evaluating \\
and Comparing the \\
Safety and \\
Efficiency of \\
ASC09/Ritonavir \\
and \\
Lopinavir/Ritonavir \\
for Confirmed \\
Cases of Novel \\
Coronavirus \\
Pneumonia \\
(COVID-19)
\end{tabular} & \begin{tabular}{|} 
Experimental group- \\
Conventional \\
standardized \\
treatment and \\
ASC09/Ritonavir \\
(80 patients)
\end{tabular} & $\begin{array}{l}\text { Control group- } \\
\text { Conventional } \\
\text { standardized } \\
\text { treatment and } \\
\text { Lopinavir/ } \\
\text { Ritonavir ( } 80 \\
\text { patients) }\end{array}$ & - & - & $\begin{array}{c}\text { The incidence of } \\
\text { the composite } \\
\text { adverse outcome } \\
\text { within } 14 \text { days } \\
\text { after admission: } \\
\text { Defined as (one } \\
\text { of them) } \mathrm{SpO}_{2}<= \\
93 \% \text { without } \\
\text { oxygen } \\
\text { supplementation, } \\
\mathrm{PaO}_{2} / \mathrm{FiO}_{2}<= \\
300 \mathrm{mmH} \text { or } \\
\mathrm{RR}<=30 \text { breaths } \\
\text { per minute. }\end{array}$ & $\begin{array}{l}\text { The First } \\
\text { Affiliated } \\
\text { Hospital of } \\
\text { Zhejiang } \\
\text { University } \\
\text { School of } \\
\text { Medicine }\end{array}$ \\
\hline
\end{tabular}




\begin{tabular}{|c|c|c|c|c|c|c|c|}
\hline $\begin{array}{c}\text { Identification } \\
\text { Number }\end{array}$ & Public Title & Group 1 & Group 2 & Group 3 & Group 4 & $\begin{array}{l}\text { Primary } \\
\text { Outcome }\end{array}$ & $\begin{array}{l}\text { Primary } \\
\text { Sponsor }\end{array}$ \\
\hline ChiCTR2000029741 & \begin{tabular}{|c|} 
Efficacy of \\
Chloroquine and \\
Lopinavir/ \\
Ritonavir in \\
mild/general novel \\
coronavirus \\
(COVID-19) \\
infections: a \\
prospective, open- \\
label, multicenter \\
randomized \\
controlled clinical \\
study \\
\end{tabular} & \begin{tabular}{|} 
Experimental group- \\
Chloroquine \\
Phosphate (56 \\
patients)
\end{tabular} & $\begin{array}{l}\text { Control group- } \\
\text { Lopinavir / } \\
\text { Ritonavir (56 } \\
\text { patients) }\end{array}$ & - & - & \begin{tabular}{|c|} 
Oxygenation \\
index during \\
treatment; \\
Peripheral blood \\
cell count; \\
C-reactive \\
protein; \\
procalcitonin
\end{tabular} & $\begin{array}{l}\text { The Fifth } \\
\text { Affiliated } \\
\text { Hospital Sun } \\
\text { Yat-Sen } \\
\text { University }\end{array}$ \\
\hline ChiCTR2000030187 & $\begin{array}{l}\text { Clinical study for } \\
\text { Lopinavir and } \\
\text { Ritonavir in the } \\
\text { treatment of novel } \\
\text { coronavirus } \\
\text { pneumonia } \\
\text { (COVID-19) } \\
\end{array}$ & \begin{tabular}{|} 
Experimental group- \\
Lopinavir and \\
Ritonavir Tablets \\
(30 patients)
\end{tabular} & $\begin{array}{l}\text { Control group- } \\
\text { Routine } \\
\text { symptomatic } \\
\text { support treatment } \\
\text { (30 patients) }\end{array}$ & - & - & $\begin{array}{c}\text { Endotracheal } \\
\text { intubation rate; } \\
\text { Mortality }\end{array}$ & $\begin{array}{c}\text { Jingzhou } \\
\text { First People's } \\
\text { Hospital }\end{array}$ \\
\hline NCT04315948 & \begin{tabular}{|} 
Multi-centre, \\
Adaptive, \\
Randomized Trial \\
of the Safety and \\
Efficacy of \\
Treatments of \\
COVID-19 in \\
Hospitalized Adults
\end{tabular} & $\begin{array}{c}\text { Experimental group- } \\
\text { Remdesivir will be } \\
\text { administered as a } \\
200 \text { mg intravenous } \\
\text { loading dose on Day } \\
1 \text {, followed by a } 100 \\
\text { mg once-daily } \\
\text { intravenous upto } 10 \\
\text { days total course } \\
\text { (620 patients) }\end{array}$ & \begin{tabular}{|c}
$\begin{array}{c}\text { Experimental } \\
\text { group- }\end{array}$ \\
Lopinavir/ritonavir \\
(400 lopinavir \\
mg/100 mg \\
ritonavir) will be \\
administered every \\
$12 \mathrm{~h}$ for 14 days in \\
tablet form ( 620 \\
patients)
\end{tabular} & 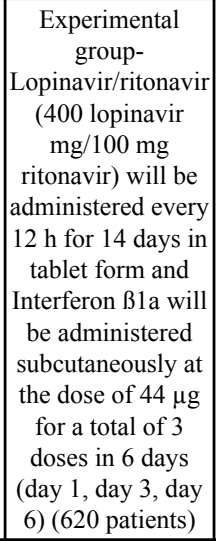 & \begin{tabular}{|c|} 
Experimental group- \\
Hydroxychloroquine \\
will be administered \\
orally as a loading \\
dose of $400 \mathrm{mg}$ \\
twice daily for one \\
day followed by 400 \\
mg once daily for 9 \\
days ( 620 patients)
\end{tabular} & $\begin{array}{l}\text { Percentage of } \\
\text { subjects } \\
\text { reporting each } \\
\text { severity rating } \\
\text { on a 7-point } \\
\text { ordinal scale }\end{array}$ & $\begin{array}{c}\text { Institut } \\
\text { National de } \\
\text { la Santé Et } \\
\text { de la } \\
\text { Recherche } \\
\text { Médicale, } \\
\text { France }\end{array}$ \\
\hline NCT04321616 & $\begin{array}{c}\text { The (Norwegian) } \\
\text { NOR Solidarity } \\
\text { Multicenter Trial } \\
\text { on the Efficacy of } \\
\text { Different Anti-viral } \\
\text { Drugs in SARS- } \\
\text { CoV-2 Infected } \\
\text { Patients }\end{array}$ & $\begin{array}{l}\text { Experimental group- } \\
\text { Hydroxychloroquine } \\
\text { will be given orally } \\
\text { (in the ICU in } \\
\text { gastrointestinal } \\
\text { tubes) with } 800 \mathrm{mg} \\
\text { x } 2 \text { loading dose } \\
\text { followed by } 400 \mathrm{mg} \\
\text { x } 2 \text { every day for a } \\
\text { total of } 10 \text { days }\end{array}$ & $\begin{array}{c}\text { Experimental } \\
\text { group- Remdesivir } \\
\text { will be given } \\
\text { intravenously } 100 \\
\text { mg daily for the } \\
\text { duration of the } \\
\text { hospitalization and } \\
\text { up to } 10 \text { days total } \\
\text { course. A loading } \\
\text { dose of } 200 \text { mg at } \\
\text { inclusion will be } \\
\text { given }\end{array}$ & $\begin{array}{l}\text { - Control group- } \\
\text { The standard of } \\
\text { care will be } \\
\text { supplied to all } \\
\text { patients not } \\
\text { receiving a drug } \\
\text { intervention }\end{array}$ & - & $\begin{array}{l}\text { All-cause in- } \\
\text { hospital } \\
\text { mortality }\end{array}$ & $\begin{array}{l}\text { Oslo } \\
\text { University } \\
\text { Hospital }\end{array}$ \\
\hline NCT04280705 & $\begin{array}{c}\text { A Multicenter, } \\
\text { Adaptive, } \\
\text { Randomized } \\
\text { Blinded Controlled } \\
\text { Trial of the Safety } \\
\text { and Efficacy of } \\
\text { Investigational } \\
\text { Therapeutics for } \\
\text { the Treatment of } \\
\text { COVID-19 in } \\
\text { Hospitalized Adults }\end{array}$ & \begin{tabular}{|} 
Control group- \\
Placebo \\
Comparator: $200 \mathrm{mg}$ \\
of Remdesivir \\
placebo \\
administered \\
intravenously on \\
Day 1 , followed by \\
a 100 mg once-daily \\
maintenance dose of \\
Remdesivir placebo \\
while hospitalized \\
for up to a 10 days \\
total course $(286$ \\
patients)
\end{tabular} & $\begin{array}{c}\text { Experimental } \\
\text { group- } 200 \text { mg of } \\
\text { Remdesivir } \\
\text { administered } \\
\text { intravenously on } \\
\text { Day } 1 \text {, followed by } \\
\text { a } 100 \text { mg once- } \\
\text { daily maintenance } \\
\text { dose of Remdesivir } \\
\text { while hospitalized } \\
\text { for up to a } 10 \text { days } \\
\text { total course ( } 286 \\
\text { patients) }\end{array}$ & - & - & $\begin{array}{l}\text { Time to } \\
\text { recovery; } \\
\text { Percentage of } \\
\text { subjects } \\
\text { reporting each } \\
\text { severity rating } \\
\text { on the 7-point } \\
\text { ordinal scale }\end{array}$ & $\begin{array}{c}\text { National } \\
\text { Institute of } \\
\text { Allergy and } \\
\text { Infectious } \\
\text { Diseases } \\
\text { (NIAID) }\end{array}$ \\
\hline
\end{tabular}


(Table 2) contd.....

\begin{tabular}{|c|c|c|c|c|c|c|c|}
\hline $\begin{array}{c}\text { Identification } \\
\text { Number }\end{array}$ & Public Title & Group 1 & Group 2 & Group 3 & Group 4 & $\begin{array}{l}\text { Primary } \\
\text { Outcome }\end{array}$ & $\begin{array}{l}\text { Primary } \\
\text { Sponsor }\end{array}$ \\
\hline NCT04333589 & $\begin{array}{l}\text { The Mechanism, } \\
\text { Clinical Outcome } \\
\text { and Therapeutic } \\
\text { Intervention of } \\
\text { Coronavirus } \\
\text { Disease } 2019 \\
\text { Patients Whose } \\
\text { Nucleic Acids } \\
\text { Changed From } \\
\text { Negative to } \\
\text { Positive }\end{array}$ & $\begin{array}{l}\text { Experimental group- } \\
\text { Favipiravir group- } \\
\text { On the 1st day, } \\
1600 \mathrm{mg} \text { each time, } \\
\text { twice a day; from } \\
\text { the } 2 \text { nd to the } 7 \text { th } \\
\text { day, } 600 \mathrm{mg} \text { each } \\
\text { time, twice a day. } \\
\text { Oral administration, } \\
\text { the maximum } \\
\text { number of days } \\
\text { taken is not more } \\
\text { than } 14 \text { days }\end{array}$ & - & - & - & $\begin{array}{l}\text { Viral nucleic } \\
\text { acid test } \\
\text { negative } \\
\text { conversion rate } \\
\text { [ Time Frame: } \\
5 \text { months ] }\end{array}$ & $\begin{array}{c}\text { Peking } \\
\text { University } \\
\text { First } \\
\text { Hospital }\end{array}$ \\
\hline
\end{tabular}

The data of recent clinical trials of antiviral is collected, separated and compiled from $\mathrm{https}: / / \mathrm{www} . c l i n i c a l t r i a l s . g o v /$ and $\mathrm{http}: / / \mathrm{www} . c h i c t r .0 r g . c n / \mathrm{enindex.aspx}$

\subsection{Antiparasite Drugs}

The use of chloroquine as an antiviral agent is crucial for preventing malaria, autoimmune diseases, and amoebiosis infections [51]. The studies show that intravesicular-pH controls cell function and increases the $\mathrm{pH}$-endosomal required to fuse the virus into a host organism, including glycosylation trimming. Chloroquine prevents vacuole and endocytosis from moving protozoans. Chloroquine is known to be useful either as prophylaxis or as a therapeutic agent. Chloroquine enables the inflow of responsible zinc to inhibit the in-vitro function of RNA polymerase [52 - 54]. Hydroxychloroquine is less toxic than the analogue derivative of chloroquine. Hydroxychloroquine was reported to show cell culture activity during the SARS-CoV epidemic. The pharmacokinetic study showed that hydroxychloroquine was found to be as effective as chloroquine in the treatment of SARS-CoV-2 due to a lack of experimental evidence [56, 57].
Ivermectin is a broad-spectrum FDA approved parasitic drug that shows activity against COVID-19 as a second-line drug. Ivermectin has a wide range of anti-viral activity against large numbers of viruses under in vitro conditions as it prevents viral replication. A single treatment with ivermectin reduced the virus to 5000 times in culture within 48 hours, but no further reduction to 72 hours. Ivermectin was known to inhibit the nuclear import of viruses and host proteins. It has been reported that the integrase protein (IN) of viruses and the importin (IMP5-007 / $\beta 1$ ) heterodimer is responsible for IN nuclear import. As most RNA viruses rely on IMP / $\beta 1$ during infection, ivermectin directly affects it and inhibits virus replication [58]. Several clinical trials to test therapeutic potency in 2019-nCOV started in different hospitals and universities. Several patient age groups were used to control adverse effects. The list of recent clinical trials of anti-parasitic drugs in COVID-19 patients is shown in Table 3.

Table 3. Clinical trials of Antiparasitic drugs in COVID-19 patients.

\begin{tabular}{|c|c|c|c|c|c|c|c|}
\hline $\begin{array}{c}\text { Identification } \\
\text { number }\end{array}$ & Public Title & Group 1 & Group 2 & Group 3 & Group 4 & Outcome & Sponsor \\
\hline ChiCTR2000031782 & $\begin{array}{l}\text { A questionnaire investigation of } \\
\text { hydroxychloroquine for its } \\
\text { potential protective effect against } \\
\text { Severe Acute Respiratory } \\
\text { Syndromes-coronavirus-2 } \\
\text { infection }\end{array}$ & \begin{tabular}{|c|} 
Patients with LE and are \\
taking hydroxychloroquine \\
(200 patients); another \\
group with LE does not take \\
hydroxychloroquine (50 \\
patients)
\end{tabular} & $\begin{array}{c}\text { Patients with } \\
\text { dermatomyositis and are } \\
\text { taking hydroxychloroquine } \\
\text { (200 patients); another } \\
\text { group with dermatomyositis } \\
\text { does not take } \\
\text { hydroxychloroquine (100 } \\
\text { patients) }\end{array}$ & \begin{tabular}{|} 
Patients with RA \\
and are taking \\
hydroxychloroquine \\
(50 patients); \\
another group with \\
RA are not take \\
hydroxychloroquine \\
(200 patients)
\end{tabular} & \begin{tabular}{|c|} 
Patients with \\
rosacea and are \\
taking \\
hydroxychloroquine \\
(200 patients); \\
another group with \\
rosacea does not \\
take \\
hydroxychloroquine \\
(200 patients) \\
\end{tabular} & \begin{tabular}{|c|} 
Incidence of \\
SARS-CoV-2 \\
infection \\
(including \\
confirmed \\
SARS-CoV-2 \\
detection, but \\
might \\
asymptomatic)
\end{tabular} & $\begin{array}{l}\text { The Second } \\
\text { Xiangya } \\
\text { Hospital of } \\
\text { Central South } \\
\text { University }\end{array}$ \\
\hline ChiCTR2000031204 & $\begin{array}{c}\text { A multicenter, single-blind, } \\
\text { randomized controlled clinical } \\
\text { trial for chloroquine phosphate in } \\
\text { the treatment of } 2019 \text { novel } \\
\text { coronavirus-infected pneumonia }\end{array}$ & $\begin{array}{c}\text { Experimental group- Oral } \\
\text { chloroquine phosphate } \\
\text { tablets (150 patients) }\end{array}$ & $\begin{array}{c}\text { Control group- Oral placebo } \\
\text { group (150 patients) }\end{array}$ & - & - & \begin{tabular}{|c|}
$\begin{array}{c}\text { Clearance time } \\
\text { of virus RNA }\end{array}$ \\
\end{tabular} & $\begin{array}{l}\text { Beijing you'an } \\
\text { Hospital; } \\
\text { Capital } \\
\text { Medical } \\
\text { University }\end{array}$ \\
\hline ChiCTR2000031174 & $\begin{array}{c}\text { Effectiveness and safety of } \\
\text { hydroxychloroquine sulfate in the } \\
\text { preventive treatment of novel } \\
\text { coronavirus pneumonia } \\
\text { (COVID-19) }\end{array}$ & $\begin{array}{c}\text { Experimental group- } \\
\text { Hydroxychloroquine (1000 } \\
\text { patients) }\end{array}$ & $\begin{array}{l}\text { Control group- Placebo } \\
\text { (1000 patients) }\end{array}$ & - & - & $\begin{array}{l}\text { COVID-19 } \\
\text { Nucleic acid }\end{array}$ & \begin{tabular}{|c} 
Shanghai \\
Public Health \\
Clinical \\
Center
\end{tabular} \\
\hline ChiCTR2000030054 & $\begin{array}{l}\text { An open randomized controlled } \\
\text { trial for Chloroquine phosphate } \\
\text { and Hydroxychloroquine sulfate } \\
\text { in the treatment of mild and } \\
\text { common novel coronavirus } \\
\text { pneumonia (COVID-19) }\end{array}$ & \begin{tabular}{|c|} 
Experimental group- \\
Hydroxychloroquine sulfate \\
$0.2 \mathrm{~g}$ bid $\mathrm{x} 14$ days a day \\
(40 patients)
\end{tabular} & $\begin{array}{l}\text { Experimental group- The } \\
\text { first dose of chloroquine } \\
\text { phosphate was } 1 \text { gx } 2 \text { days, } \\
\text { and the third day was } \\
0.5 \text { gx } 12 \text { days } \\
\text { (40 patients) }\end{array}$ & \begin{tabular}{c|} 
Recommended \\
treatment plan for \\
novel coronavirus \\
pneumonia \\
diagnosis and \\
treatment plan \\
$(20$ patients $)$ \\
\end{tabular} & - & $\begin{array}{c}\text { Clinical } \\
\text { recovery time }\end{array}$ & $\begin{array}{l}\text { Zhongshan } \\
\text { Hospital } \\
\text { Affiliated to } \\
\text { Xiamen } \\
\text { University }\end{array}$ \\
\hline ChiCTR2000029868 & $\begin{array}{l}\text { Hydroxychloroquine treating } \\
\text { novel coronavirus pneumonia } \\
\text { (COVID-19): a randomized } \\
\text { controlled, open label, } \\
\text { multicenter trial }\end{array}$ & $\begin{array}{c}\text { Experimental group- Oral } \\
\text { hydroxychloroquine sulfate } \\
\text { tablets (180 patients) }\end{array}$ & $\begin{array}{c}\text { Conventional treatment } \\
\text { meet the Guideline (180 } \\
\text { patients) }\end{array}$ & - & - & $\begin{array}{l}\text { Viral nucleic } \\
\text { acid test }\end{array}$ & $\begin{array}{l}\text { Ruijin } \\
\text { Hospital; } \\
\text { Shanghai } \\
\text { Jiaotong } \\
\text { University } \\
\text { School of } \\
\text { Medicine }\end{array}$ \\
\hline
\end{tabular}




\begin{tabular}{|c|c|c|c|c|c|c|c|}
\hline $\begin{array}{c}\text { Identification } \\
\text { number }\end{array}$ & Public Title & Group 1 & Group 2 & Group 3 & Group 4 & Outcome & Sponsor \\
\hline NCT04374279 & $\begin{array}{c}\text { A Phase II Trial to Promote } \\
\text { Recovery From COVID-19 With } \\
\text { Ivermectin or Endocrine Therapy }\end{array}$ & \begin{tabular}{|c|} 
Experimental group- \\
Bicalutamide $150 \mathrm{Mg}$ Oral \\
Tablet for 7 days, and \\
standard of care
\end{tabular} & \begin{tabular}{|c|} 
Experimental group- \\
Ivermectin $3 \mathrm{Mg} \mathrm{Tab}$ \\
(Ivermectin $600 \mu \mathrm{g} / \mathrm{kg}$ (up \\
to a maximum dose of \\
$60 \mathrm{mg}$ ) by mouth daily for 3 \\
days)
\end{tabular} & - & - & \begin{tabular}{|c|} 
Number of \\
participants \\
who have \\
clinical \\
improvement \\
at day 7 after \\
randomization
\end{tabular} & \begin{tabular}{|c} 
Sidney \\
Kimmel \\
Comprehensive \\
Cancer Center \\
at Johns \\
Hopkins
\end{tabular} \\
\hline NCT04341493 & \begin{tabular}{|c|} 
Treatment With \\
Hydroxychloroquine vs \\
Nitazoxanide + \\
Hydroxychloroquine in Patients \\
With COVID-19 With Risk \\
Factors for Poor Outcome
\end{tabular} & $\begin{array}{c}\text { Experimental group- } \\
\text { Hydroxychloroquine } 400 \\
\text { mg PO every } 12 \text { hours for } \\
\text { two days and then } 200 \mathrm{mg} \\
\text { PO every } 12 \text { hours for four } \\
\text { days + Nitazoxanide } 500 \\
\text { mg PO every } 6 \text { hours for six } \\
\text { days }\end{array}$ & \begin{tabular}{|c|} 
Active comparator- \\
Hydroxychloroquine 200 \\
mg PO every 12 hours for 7 \\
days
\end{tabular} & - & - & $\begin{array}{l}\text { Mechanical } \\
\text { ventilation } \\
\text { requirement }\end{array}$ & $\begin{array}{c}\text { Hugo Mendieta } \\
\text { Zeron }\end{array}$ \\
\hline NCT04363450 & $\begin{array}{l}\text { Hydroxychloroquine as Primary } \\
\text { Prophylaxis for COVID-19 in } \\
\text { Healthcare Workers (HCQPreP) }\end{array}$ & \begin{tabular}{|c|} 
Experimental group- \\
Hydroxychloroquine \\
loading dose will be given \\
as $400 \mathrm{mg}$ for two doses 12 \\
hours apart. This will then \\
be followed by maintenance \\
dosing of $200 \mathrm{mg}$ twice \\
weekly for the remainder of \\
the trial
\end{tabular} & \begin{tabular}{|c|} 
Control group- Placebo: \\
(An identical placebo will \\
be administered on an \\
identical dosing interval and \\
frequency)
\end{tabular} & - & - & $\begin{array}{l}\text { Incidence of } \\
\text { symptomatic } \\
\text { COVID-19 } \\
\text { infection in } \\
\text { healthcare } \\
\text { workers }\end{array}$ & \begin{tabular}{|c|} 
Louisiana State \\
University \\
Health \\
Sciences \\
Center in New \\
Orleans
\end{tabular} \\
\hline NCT04346667 & $\begin{array}{l}\text { Post-Exposure Prophylaxis for } \\
\text { Asymptomatic SARS-CoV-2 } \\
\text { COVID-19 Patients With } \\
\text { choloroquinE Compounds }\end{array}$ & \begin{tabular}{|c|} 
Experimental group- \\
Hydroxychloroquine Sulfate \\
Regular dose \\
(Hydroxychloroquine \\
administered based off of \\
in-vitro pharmacokinetics \\
study) \\
\end{tabular} & \begin{tabular}{|c|} 
Experimental group- \\
Hydroxychloroquine Sulfate \\
Loading Dose
\end{tabular} & \begin{tabular}{|c|} 
Experimental \\
group- Chloroquine \\
administered based \\
off of in-vitro \\
pharmacokinetics \\
study
\end{tabular} & $\begin{array}{l}\text { Placebo (Standard } \\
\text { of Care plus } \\
\text { placebo) }\end{array}$ & \begin{tabular}{|c|} 
RT-PCR \\
negative status
\end{tabular} & \begin{tabular}{|c|} 
Government of \\
Punjab, \\
Specialized \\
Healthcare and \\
Medical \\
Education \\
Department
\end{tabular} \\
\hline NCT04342169 & $\begin{array}{c}\text { Hydroxychloroquine for } \\
\text { Outpatients With Confirmed } \\
\text { COVID-19 }\end{array}$ & \begin{tabular}{|c|} 
Experimental group- \\
Hydroxychloroquine (HCQ \\
400mg po BID x 1 day, then \\
$200 \mathrm{mg}$ po BID x 4 days) \\
\end{tabular} & $\begin{array}{c}\text { Control group- Placebo oral } \\
\text { tablet (Placebo to be taken } \\
\text { on the same schedule as } \\
\text { HCQ) }\end{array}$ & - & - & $\begin{array}{c}\text { Duration of } \\
\text { viral shedding }\end{array}$ & $\begin{array}{c}\text { University of } \\
\text { Utah }\end{array}$ \\
\hline NCT04341441 & $\begin{array}{c}\text { Will Hydroxychloroquine Impede } \\
\text { or Prevent COVID-19: WHIP } \\
\text { COVID-19 Study }\end{array}$ & \begin{tabular}{|c|} 
Experimental group- \\
Hydroxychloroquine - Daily \\
Dosing (The daily \\
hydroxychloroquine \\
treatment arm will receive a \\
$200 \mathrm{mg}$ oral dose daily \\
following day 1 dose of 400 \\
mg orally once)
\end{tabular} & \begin{tabular}{|c|} 
Experimental group- \\
Hydroxychloroquine - \\
Weekly Dosing (The once \\
weekly randomized \\
treatment arm will receive \\
the proposed dose of \\
hydroxychloroquine for \\
prophylaxis of malaria is \\
$6.5 \mathrm{mg} / \mathrm{kg}$ per dose \\
(maximum of $400 \mathrm{mg}$ per \\
dose) administered orally \\
weekly on the same day of \\
each week)
\end{tabular} & \begin{tabular}{|} 
Placebo oral tablet \\
(Participants \\
randomized to this \\
arm will be \\
provided with daily \\
dosing of oral \\
placebo to have the \\
patients take 2 pills \\
a day)
\end{tabular} & \begin{tabular}{|c|} 
Non-Randomized \\
Active Comparator
\end{tabular} & \begin{tabular}{|c|} 
Reduction in \\
the number of \\
COVID-19 \\
infections in \\
healthcare \\
workers
\end{tabular} & \begin{tabular}{|c|} 
Henry Ford \\
Health System
\end{tabular} \\
\hline NCT04392427 & \begin{tabular}{|c|} 
Effect of a Combination of \\
Nitazoxanide, Ribavirin and \\
Ivermectin Plus Zinc Supplement \\
on the Clearance of COVID-19: a \\
Pilot Sequential Clinical Trial
\end{tabular} & \begin{tabular}{|c|} 
Experimental group- Will \\
receive a combination of \\
Nitazoxanide, Ribavirin \\
and Ivermectin or a duration \\
of seven days (100 patients)
\end{tabular} & $\begin{array}{l}\text { Control group- will not } \\
\text { receive anything }\end{array}$ & - & - & \begin{tabular}{|c|} 
PCR FOR \\
COVID-19 \\
will be done on \\
serial visits till \\
turn to \\
negative, first \\
after 5 day then \\
serial every 48 \\
hours till \\
become \\
negative for \\
two \\
consecutive \\
samples.
\end{tabular} & $\begin{array}{l}\text { Mansoura } \\
\text { University }\end{array}$ \\
\hline NCT04390022 & \begin{tabular}{|c|} 
Pilot Study to Evaluate the \\
Potential of Ivermectin to Reduce \\
COVID-19 Transmission
\end{tabular} & \begin{tabular}{|c|} 
Experimental group- \\
Participants on this arm will \\
receive a single, oral dose \\
of Ivermectin $400 \mathrm{mcg} / \mathrm{kg}$ at \\
the enrolment visit
\end{tabular} & \begin{tabular}{|} 
Control group- Participants \\
on the arm will receive a \\
single, oral dose of placebo \\
tablets at the enrolment visit
\end{tabular} & - & - & \begin{tabular}{|c|} 
Proportion of \\
patients with a \\
positive SARS- \\
CoV-2 PCR \\
from a \\
nasopharyngeal \\
swab at day 7 \\
post-treatment
\end{tabular} & $\begin{array}{c}\text { Clinica } \\
\text { University of } \\
\text { Navarra, } \\
\text { University of } \\
\text { Navarra }\end{array}$ \\
\hline
\end{tabular}

The data of recent clinical trials on anti-parasitic data is collected, separated and compiled from https://www.clinicaltrials.gov/ and http://www.chictr.org.cn/enindex.aspx

\subsection{Corticosteroids}

Corticosteroids are a group of steroid hormones that regulate various physiological processes. The protective effect of steroids in COVID-19 patients was seen in various clinical studies. Several studies have demonstrated the effectiveness of corticosteroids in alleviating adverse immune system reactions. A lab study of dexamethasone infected pigs showed that one or two doses of corticosteroids could reduce cytokine expression
$[59,60]$. List of recent corticosteroid clinical trials in COVID19 patients is shown in Table 4.

\subsection{Antibodies}

Monoclonal antibodies are mainly targeted at the spike glycoprotein virus that invades host organisms. There are two functional subunits of spike protein ( $\mathrm{S} 1$ and $\mathrm{S} 2$ ), in which $\mathrm{S} 1$ is used to attach cells, and S2 is capable of fusing into the cells. 
Monoclonal antibodies can only be monovalent, and only one antigen can be identified at the same time. Antibodies neutralizing coronavirus are frequently targeted at and make incompetent S1 binding receptor domains $[62,63]$. Some antibodies identify various epitopes in the domain of receptor bindings, such as SARS-CoV neutralizing the virus competency antibodies CR 3014 and CR 3022. Table 5 shows the list of recent clinical tests of antibodies in COVID-19 patients.

Table 4. Clinical trials of corticosteroids in COVID-19 patients.

\begin{tabular}{|c|c|c|c|c|c|c|c|}
\hline $\begin{array}{c}\text { Identification } \\
\text { Number }\end{array}$ & Public Title & Group 1 & Group 2 & Group 3 & \begin{tabular}{|c|} 
Group \\
4 \\
\end{tabular} & Outcome & Sponsor \\
\hline NCT04355637 & $\begin{array}{c}\text { Inhaled Corticosteroid Treatment } \\
\text { of COVID19 Patients With } \\
\text { Pneumonia }\end{array}$ & $\begin{array}{l}\text { Control group- } \\
\text { Patients receiving } \\
\text { standard of care to } \\
\text { treat their pneumonia }\end{array}$ & $\begin{array}{l}\text { Experimental } \\
\text { group- Patients } \\
\text { receiving } \\
\text { standard of care } \\
\text { to treat their } \\
\text { pneumonia }+ \\
\text { inhaled } \\
\text { budesonide }\end{array}$ & - & - & $\begin{array}{l}\text { Proportion of } \\
\text { patients in both } \\
\text { arms fulfilling } \\
\text { the criteria for } \\
\text { treatment } \\
\text { failure }\end{array}$ & Sara Varea \\
\hline NCT04344288 & $\begin{array}{c}\text { Corticosteroids During } \\
\text { COVID-19 viral Pneumonia } \\
\text { Related to SARS- } \\
\text { Cov-2 Infection }\end{array}$ & $\begin{array}{l}\text { Experimental group- } \\
\text { Oral Prednisone } \\
\text { during } 10 \text { days }(0.75 \\
\mathrm{mg} / \mathrm{kg} / \text { day during } 5 \\
\text { days then } 20 \mathrm{mg} / \text { day } \\
\text { during } 5 \text { more days })\end{array}$ & $\begin{array}{l}\text { Control group- } \\
\text { Standard of } \\
\text { care }\end{array}$ & - & - & $\begin{array}{c}\text { Number of } \\
\text { patients with a } \\
\text { theoretical } \\
\text { respiratory } \\
\text { indication for } \\
\text { transfer to } \\
\text { intensive care } \\
\text { unit evaluated } \\
\text { by a SpO } \\
<90 \% \\
\text { stabilized at } \\
\text { rest and under } \\
\text { not more than } 5 \\
\text { L / min of } \\
\text { supplemental } \\
\text { oxygen using } \\
\text { medium } \\
\text { concentration } \\
\text { mask }\end{array}$ & $\begin{array}{l}\text { Hospices } \\
\text { Civils de } \\
\text { Lyon }\end{array}$ \\
\hline NCT04355247 & $\begin{array}{c}\text { Prophylactic Corticosteroids to } \\
\text { Prevent COVID-19 Cytokine } \\
\text { Storm }\end{array}$ & $\begin{array}{l}\text { Experimental group- } \\
\text { Methylprednisolone } \\
80 \mathrm{mg} / \mathrm{mL} \text { Injectable } \\
\text { Suspension will be } \\
\text { given daily x } 5 \text { days } \\
\text { starting upon day } 1 \text { of } \\
\text { admission to hospital. }\end{array}$ & - & - & - & \begin{tabular}{|c|} 
Clinical \\
complete \\
response \\
criteria; \\
Clinical Partial \\
Response \\
criteria
\end{tabular} & $\begin{array}{l}\text { Auxilio } \\
\text { Mutuo } \\
\text { Cancer } \\
\text { Center }\end{array}$ \\
\hline NCT04343729 & $\begin{array}{l}\text { Methylprednisolone in the } \\
\text { Treatment of Patients With Signs } \\
\text { of Severe Acute Respiratory } \\
\text { Syndrome in COVID-19 }\end{array}$ & $\begin{array}{l}\text { Experimental group- } \\
0.5 \mathrm{mg} / \mathrm{kg} \text { injectable } \\
\text { methylprednisolone } \\
\text { sodium succinate, } \\
\text { twice daily, for } 5 \\
\text { days. }\end{array}$ & $\begin{array}{l}\text { Control group- } \\
\text { Saline solution, } \\
\text { twice daily, for } \\
5 \text { days. } \\
\text { Injectable }\end{array}$ & - & - & $\begin{array}{c}\text { Mortality rate } \\
\text { at day } 28\end{array}$ & \begin{tabular}{|c|} 
Fundação \\
de \\
Medicina \\
Tropical \\
Dr. Heitor \\
Vieira \\
Dourado
\end{tabular} \\
\hline ChiCTR2000030481 & $\begin{array}{l}\text { The clinical value of } \\
\text { corticosteroid therapy timing in } \\
\text { the treatment of novel } \\
\text { coronavirus pneumonia } \\
\text { (COVID-19): a prospective } \\
\text { randomized controlled trial }\end{array}$ & $\begin{array}{l}\text { Experimental group- } \\
\text { Early corticosteroid } \\
\text { intervention group } \\
\text { (75 patients) }\end{array}$ & $\begin{array}{l}\text { Experimental } \\
\text { group- Middle- } \\
\text { late } \\
\text { corticosteroid } \\
\text { intervention } \\
\text { group (75 } \\
\text { patients) }\end{array}$ & \begin{tabular}{|c|} 
Control \\
group- No \\
corticosteroid \\
(50 patients)
\end{tabular} & - & $\begin{array}{l}\text { The time of } \\
\text { duration of } \\
\text { COVID-19 } \\
\text { nucleic acid } \\
\text { RT-PCR test } \\
\text { results of } \\
\text { respiratory } \\
\text { specimens } \\
\text { (such as throat } \\
\text { swabs) or blood } \\
\text { specimens } \\
\text { change to } \\
\text { negative. }\end{array}$ & \begin{tabular}{|c|} 
Zhongnan \\
Hospital of \\
Wuhan \\
University
\end{tabular} \\
\hline
\end{tabular}


Table 5. Clinical trials of Antibodies in COVID-19 patients.

\begin{tabular}{|c|c|c|c|c|c|c|c|}
\hline $\begin{array}{c}\text { Identification } \\
\text { Number }\end{array}$ & Public Title & Group 1 & Group 2 & Group 3 & \begin{tabular}{|c|} 
Group \\
4 \\
\end{tabular} & Outcome & Sponsor \\
\hline NCT04346589 & $\begin{array}{l}\text { Convalescent Antibodies } \\
\text { Infusion in Critically Ill } \\
\text { COVID } 19 \text { Patients }\end{array}$ & $\begin{array}{c}\text { Experimental group- } \\
\text { Antibodies } \\
\text { (immunoglobulins) } \\
\text { infusion- Biological: } \\
\text { Anti-coronavirus } \\
\text { Antibodies } \\
\text { (immunoglobulins) } \\
\text { obtained with DFPP } \\
\text { from convalescent } \\
\text { patients }\end{array}$ & - & - & - & \begin{tabular}{|c|} 
Number of \\
mechanical \\
ventilation days
\end{tabular} & $\begin{array}{l}\text { A.O. } \\
\text { Ospedale } \\
\text { Papa } \\
\text { Giovanni } \\
\text { XXIII }\end{array}$ \\
\hline NCT04341116 & $\begin{array}{c}\text { Study of TJ003234 (Anti- } \\
\text { GM-CSF Monoclonal } \\
\text { Antibody) in Subjects With } \\
\text { Severe Coronavirus Disease } \\
2019 \text { (COVID-19) }\end{array}$ & $\begin{array}{c}\text { Experimental group- } \\
\text { TJ003234 (3mg/kg): } \\
\text { patients receive a single } \\
\text { infusion }\end{array}$ & 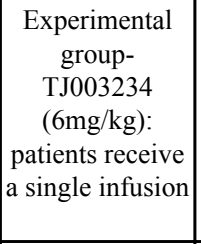 & $\begin{array}{l}\text { Control } \\
\text { group- } \\
\text { Placebo: } \\
\text { patients } \\
\text { receive a } \\
\text { single } \\
\text { infusion } \\
\end{array}$ & - & \begin{tabular}{|l|} 
Proportion $(\%)$ \\
of subjects \\
experiencing \\
deterioration in \\
clinical status
\end{tabular} & $\begin{array}{c}\text { I-Mab } \\
\text { Biopharma } \\
\text { Co. Ltd. }\end{array}$ \\
\hline NCT04351152 & $\begin{array}{c}\text { A Phase } 3 \text { Randomized, } \\
\text { Placebo-Controlled Study of } \\
\text { Lenzilumab in Hospitalized } \\
\text { Patients With COVID-19 } \\
\text { Pneumonia }\end{array}$ & $\begin{array}{c}\text { Experimental group- } \\
\text { Lenzilumab IV infusion } \\
\text { plus Standard of Care }\end{array}$ & $\begin{array}{l}\text { Control group- } \\
\text { IV infusion of } \\
\text { saline plus } \\
\text { Standard of } \\
\text { Care }\end{array}$ & - & - & $\begin{array}{l}\text { Incidence of } \\
\text { invasive } \\
\text { mechanical } \\
\text { ventilation } \\
\text { (IMV) and/or } \\
\text { Mortality }\end{array}$ & $\begin{array}{l}\text { Humanigen, } \\
\text { Inc. }\end{array}$ \\
\hline ChiCTR2000030703 & $\begin{array}{c}\text { A randomized, blinded, } \\
\text { controlled, multicenter } \\
\text { clinical trial to evaluate the } \\
\text { efficacy and safety of } \\
\text { Ixekizumab combined with } \\
\text { conventional antiviral drugs } \\
\text { in patients with novel } \\
\text { coronavirus pneumonia } \\
\text { (COVID-19) }\end{array}$ & $\begin{array}{l}\text { Experimental group- } \\
\text { Ixekizumab and } \\
\text { antiviral therapy ( } 20 \\
\text { patients) }\end{array}$ & \begin{tabular}{|} 
control group- \\
antiviral therapy \\
(20 patients)
\end{tabular} & - & - & $\begin{array}{l}\text { Lung CT; Lung } \\
\text { function; } \\
\text { Arterial blood } \\
\text { gas analysis }\end{array}$ & $\begin{array}{l}\text { Xiangya } \\
\text { Hospital of } \\
\text { Central South } \\
\text { University }\end{array}$ \\
\hline
\end{tabular}

The data of recent clinical trials on antibodies data is collected, separated and compiled from https://www.clinicaltrials.gov/ and http://www.chictr.org.cn/enindex.aspx

Table 6. Clinical trials of plasma convalescent transfusion in COVID-19 patients.

\begin{tabular}{|c|c|c|c|c|c|c|c|}
\hline $\begin{array}{c}\text { Identification } \\
\text { Number }\end{array}$ & Public Title & Group 1 & Group 2 & \begin{tabular}{|c|} 
Group \\
$\mathbf{3}$ \\
\end{tabular} & \begin{tabular}{|c|} 
Group \\
4
\end{tabular} & Outcome & Sponsor \\
\hline ChiCTR2000030039 & $\begin{array}{l}\text { Clinical study for infusing } \\
\text { convalescent plasma to treat } \\
\text { patients with new coronavirus } \\
\text { pneumonia (COVID-19) }\end{array}$ & $\begin{array}{c}\text { Experimental group- } \\
\text { Conventional therapy with } \\
\text { Infusion of convalescent plasma: } \\
200-500 \mathrm{ml}, \text { two infusions are } \\
\text { recommended (30 patients) }\end{array}$ & $\begin{array}{l}\text { Control group } \\
\text {-Conventional } \\
\text { therapy ( } 60 \\
\text { patients) }\end{array}$ & - & - & $\begin{array}{c}\text { SARS-CoV-2 } \\
\text { DNA; SARS- } \\
\text { CoV-2 antibody } \\
\text { levels }\end{array}$ & $\begin{array}{l}\text { Affiliated } \\
\text { Hospital of } \\
\text { Xuzhou } \\
\text { Medical } \\
\text { University }\end{array}$ \\
\hline ChiCTR2000030929 & $\begin{array}{l}\text { A randomized, double-blind, } \\
\text { parallel-controlled trial to } \\
\text { evaluate the efficacy and safety } \\
\text { of anti-SARS-CoV-2 virus } \\
\text { inactivated plasma in the } \\
\text { treatment of severe novel } \\
\text { coronavirus pneumonia } \\
\text { (COVID-19) }\end{array}$ & $\begin{array}{c}\text { Experimental group-Anti-SARS- } \\
\text { CoV-2 virus inactivated plasma } \\
\text { (30 patients) }\end{array}$ & $\begin{array}{l}\text { Control } \\
\text { group- } \\
\text { Ordinary } \\
\text { plasma (30 } \\
\text { patients) }\end{array}$ & - & - & $\begin{array}{l}\text { Improvement of } \\
\text { clinical } \\
\text { symptoms }\end{array}$ & $\begin{array}{l}\text { Renmin } \\
\text { Hospital of } \\
\text { Wuhan } \\
\text { University }\end{array}$ \\
\hline ChiCTR2000030702 & $\begin{array}{l}\text { Convalescent plasma for the } \\
\text { treatment of common } \\
\text { COVID-19: a prospective } \\
\text { randomized controlled trial }\end{array}$ & $\begin{array}{c}\text { Experimental group- } \\
\text { Conventional treatment and } \\
\text { convalescent plasma therapy ( } 25 \\
\text { patients) }\end{array}$ & $\begin{array}{l}\text { Control } \\
\text { group- } \\
\text { Conventional } \\
\text { treatment ( } 25 \\
\text { patients) }\end{array}$ & - & - & $\begin{array}{l}\text { Time to clinical } \\
\text { recovery after } \\
\text { randomization }\end{array}$ & $\begin{array}{l}\text { China-Japan } \\
\text { friendship } \\
\text { hospital }\end{array}$ \\
\hline
\end{tabular}




\begin{tabular}{|c|c|c|c|c|c|c|c|}
\hline $\begin{array}{l}\text { Identification } \\
\text { Number }\end{array}$ & Public Title & Group 1 & Group 2 & $\begin{array}{c}\text { Group } \\
\mathbf{3}\end{array}$ & $\begin{array}{c}\text { Group } \\
4\end{array}$ & Outcome & Sponsor \\
\hline NCT04358783 & $\begin{array}{c}\text { Convalescent Plasma } \\
\text { Compared to the Best Available } \\
\text { Therapy for the Treatment of } \\
\text { SARS-CoV-2 Pneumonia }\end{array}$ & \begin{tabular}{|c|} 
Experimental group- \\
Convalescent Plasma from cured \\
COVID-19 patients and \\
supportive management \\
depending on individual needs
\end{tabular} & $\begin{array}{c}\text { Experimental } \\
\text { group- } \\
\text { Receive } \\
\text { supportive } \\
\text { management } \\
\text { depending on } \\
\text { individual } \\
\text { needs }\end{array}$ & - & - & - & \begin{tabular}{|c|} 
Hospital \\
Universitario \\
Dr. Jose E. \\
Gonzalez
\end{tabular} \\
\hline NCT04357106 & $\begin{array}{c}\text { COPLA Study: Treatment of } \\
\text { Severe Forms of Coronavirus } \\
\text { infection With Convalescent } \\
\text { Plasma }\end{array}$ & $\begin{array}{c}\text { Experimental group- } 200 \mathrm{ml} \text { of } \\
\text { convalescent Plasma, single dose }\end{array}$ & - & - & - & \begin{tabular}{|c|} 
Lung \\
injury $(\mathrm{PaO} 2 / \mathrm{FiO} 2$ \\
relation); Overall \\
survival
\end{tabular} & \begin{tabular}{|c|} 
Centro de \\
Hematología \\
y Medicina \\
Interna
\end{tabular} \\
\hline NCT04360486 & \begin{tabular}{|c|} 
Treatment \\
Of CORONAVIRUS DISEASE \\
2019 (COVID-19) With Anti- \\
Sars-CoV-2 \\
Convalescent Plasma \\
(ASCoV2CP)
\end{tabular} & $\begin{array}{c}\text { Anti-Sars-CoV-2 Convalescent } \\
\text { Plasma- } \\
\text { Fresh frozen plasma, plasma } \\
\text { Frozen for } 24 \text { hours (PF-24), or } \\
\text { liquid plasma }\end{array}$ & - & - & - & - & \begin{tabular}{|c|} 
U.S. Army \\
Medical \\
Research and \\
Development \\
Command
\end{tabular} \\
\hline NCT04377672 & $\begin{array}{c}\text { Safety and Pharmacokinetics of } \\
\text { Human Convalescent Plasma } \\
\text { in High Risk Children Exposed } \\
\text { or Infected With SARS-CoV-2 }\end{array}$ & $\begin{array}{c}\text { Experimental group- Anti- } \\
\text { SARS-CoV-2 Human } \\
\text { Convalescent Plasma (1-2 units } \\
\text { (200-250 mL per unit) of plasma } \\
\text { with anti-SARS-CoV-19 titers of } \\
\geq 1: 320) \text { The total volume (mL) } \\
\text { infused will be based on weight } \\
(5 \mathrm{~mL} / \mathrm{kg}) \text { with a maximum } \\
\text { volume of } 500 \mathrm{~mL}\end{array}$ & - & - & - & $\begin{array}{l}\text { Safety of } \\
\text { treatment with } \\
\text { high-titer anti- } \\
\text { SARS-CoV-2 } \\
\text { plasma as } \\
\text { assessed by } \\
\text { adverse events }\end{array}$ & $\begin{array}{l}\text { Johns } \\
\text { Hopkins } \\
\text { University }\end{array}$ \\
\hline NCT04364737 & $\begin{array}{l}\text { Convalescent Plasma to Limit } \\
\text { COVID-19 Complications in } \\
\text { Hospitalized Patients }\end{array}$ & $\begin{array}{c}\text { Experimental group- SARS- } \\
\text { CoV-2 convalescent plasma }(1-2 \\
\text { units; } \sim 250-500 \mathrm{~mL})\end{array}$ & \begin{tabular}{|l|} 
Control \\
group- \\
Lactated \\
ringer's \\
solution or \\
sterile saline \\
solution
\end{tabular} & - & - & \begin{tabular}{|} 
Percentage of \\
subjects reporting \\
each severity \\
rating on WHO \\
ordinal scale for \\
clinical \\
improvement
\end{tabular} & $\begin{array}{l}\text { NYU } \\
\text { Langone } \\
\text { Health }\end{array}$ \\
\hline
\end{tabular}

The data of recent clinical trials on plasma convalescent transfusion is collected, separated and compiled from https://www.clinicaltrials.gov/ and http://www.chictr.org.cn/enindex.aspx

Table 7. Clinical trials of vaccines in COVID-19 patients.

\begin{tabular}{|c|c|c|c|c|c|c|c|}
\hline $\begin{array}{l}\text { Identification } \\
\text { Number }\end{array}$ & Public Title & Group 1 & Group 2 & Group 3 & $\begin{array}{c}\text { Group } \\
4\end{array}$ & Outcome & Sponsor \\
\hline ChiCTR2000031781 & \begin{tabular}{|} 
A randomized, double-blinded, \\
placebo-controlled phase II \\
clinical trial for Recombinant \\
Novel Coronavirus (2019- \\
nCOV) Vaccine (Adenovirus \\
Vector) in healthy adults aged \\
above 18 years
\end{tabular} & \begin{tabular}{|c|} 
Experimental group- Middle \\
dose (1E11vp) \\
(250 patients)
\end{tabular} & $\begin{array}{c}\text { Experimental } \\
\text { group- Low } \\
\text { dose } \\
(5 \mathrm{E} 10 \mathrm{vp}) \\
(125 \\
\text { patients })\end{array}$ & $\begin{array}{l}\text { Control } \\
\text { group- } \\
\text { Placebo } \\
(125 \\
\text { patients) }\end{array}$ & - & $\begin{array}{c}\text { Adverse reactions } 0-14 \\
\text { days post vaccination; } \\
\text { Anti-S antibody IgG } \\
\text { titer on day } 28 \text { post } \\
\text { vaccination; Anti- } \\
\text { SARS-CoV-2 } \\
\text { neutralizing antibody } \\
\text { titer on day } 28 \text { post } \\
\text { vaccination }\end{array}$ & $\begin{array}{l}\text { Jiangsu } \\
\text { Provincial } \\
\text { Center for } \\
\text { Disease } \\
\text { Control and } \\
\text { Prevention }\end{array}$ \\
\hline NCT04276896 & $\begin{array}{c}\text { Phase I/II Multicenter Trial of } \\
\text { Lentiviral } \\
\text { Minigene vaccine (LV-SMENP) } \\
\text { of COVID-19 Coronavirus }\end{array}$ & \begin{tabular}{|c|} 
Experimental group- \\
Injection and infusion of \\
LV-SMENP-DC vaccine and \\
antigen-specific CTLs \\
(Patients will receive \\
approximately $5 \times 10^{\wedge} 6 \mathrm{LV}-$ \\
DC vaccine and $1 \times 10^{\wedge} 8$ \\
CTLs via sub-cutaneous \\
injections and iv infusions, \\
respectively.
\end{tabular} & - & - & - & \begin{tabular}{|c|} 
Clinical improvement \\
based on the 7-point \\
scale; Lower Murray \\
lung injury score
\end{tabular} & $\begin{array}{c}\text { Shenzhen } \\
\text { Geno-Immune } \\
\text { Medical } \\
\text { Institute }\end{array}$ \\
\hline NCT04348370 & \begin{tabular}{|c|} 
Bacillus Calmette- \\
Guerin vaccination as Defense \\
Against SARS-CoV-2: A \\
Randomized Controlled Trial to \\
Protect Health Care Workers by \\
Enhanced Trained Immune \\
Responses
\end{tabular} & \begin{tabular}{|c|} 
Experimental group- \\
BCG vaccine (A single dose \\
will consist of $0.1 \mathrm{~mL}$ \\
$\left(\sim 2 \times 10^{\wedge} 5 \mathrm{CFU}\right)$ will be \\
administered by slow \\
intradermal injection using a \\
25 gauge $/ 0.5 \mathrm{~mm}$ syringe in \\
the deltoid area.)
\end{tabular} & $\begin{array}{l}\text { Control } \\
\text { group- } \\
\text { Vaccine (A } \\
\text { single dose } \\
\text { will consist } \\
\text { of } 0.1 \mathrm{~mL} \\
\text { saline) }\end{array}$ & - & - & $\begin{array}{c}\text { Incidence of COVID } \\
19 \text { Infection } \\
\text { [Time Frame: } 6 \\
\text { months] }\end{array}$ & $\begin{array}{c}\text { Texas A\&M } \\
\text { University }\end{array}$ \\
\hline
\end{tabular}




\begin{tabular}{|c|c|c|c|c|c|c|c|}
\hline $\begin{array}{c}\text { Identification } \\
\text { Number }\end{array}$ & Public Title & Group 1 & Group 2 & Group 3 & $\begin{array}{c}\text { Group } \\
4\end{array}$ & Outcome & Sponsor \\
\hline NCT04361552 & \begin{tabular}{|c|} 
Tociluzumab for Cytokine \\
Release Syndrome With SARS- \\
CoV-2: An Open-Labeled, \\
Randomized Phase 3 Trial
\end{tabular} & \begin{tabular}{|c|} 
Experimental group- Arm I: \\
Patients receive tocilizumab \\
IV every 12 hours for up to 3 \\
doses in the absence of \\
disease progression or \\
unacceptable toxicity. \\
Patients also receive \\
standard of care
\end{tabular} & \begin{tabular}{|c|} 
Active \\
Comparator- \\
Arm II: \\
Patients \\
receive \\
standard of \\
care
\end{tabular} & - & - & \begin{tabular}{|c|} 
7-day length of \\
invasive mechanical \\
ventilation (MV) ; 30- \\
day mortality rate
\end{tabular} & $\begin{array}{c}\text { Emory } \\
\text { University }\end{array}$ \\
\hline NCT04359667 & \begin{tabular}{|c} 
Serum IL-6 and Soluble IL-6 \\
Receptor in Severe COVID-19 \\
Pneumonia Treated With \\
Tocilizumab
\end{tabular} & $\begin{array}{c}\text { Experimental group- } \\
\text { Tocilizumab } 20 \mathrm{MG} / \mathrm{ML} \\
\text { Intravenous Solution } \\
\text { [ACTEMRA] }(1-8 \mathrm{mg} \text { per } \\
\text { kg of body weight once, } \\
\text { maximal } 800 \mathrm{mg} \text { per dose } \\
\text { and also standard of care } \\
\text { treatment) }\end{array}$ & - & - & - & $\begin{array}{l}\text { Evaluate the role of } \\
\text { laboratory markers as } \\
\text { predictors of survival }\end{array}$ & $\begin{array}{l}\text { University } \\
\text { Hospital for } \\
\text { Infectious } \\
\text { Diseases, } \\
\text { Croatia }\end{array}$ \\
\hline NCT04283461 & $\begin{array}{c}\text { Phase I, Open-Label, Dose- } \\
\text { Ranging Study of the Safety and } \\
\text { Immunogenicity of 2019-nCoV } \\
\text { Vaccine (mRNA-1273) in } \\
\text { Healthy Adults }\end{array}$ & $\begin{array}{c}\text { Experimental three different } \\
\text { groups receive } 25,100,250 \\
\text { mcg of mRNA-1273, } \\
\text { respectively, administered } \\
\text { through IM between } 18-55 \\
\text { years age range }\end{array}$ & \begin{tabular}{|c|}
$\begin{array}{c}\text { Experimental } \\
\text { three }\end{array}$ \\
different \\
groups \\
receive \\
$25,100,250$ \\
mcg of \\
mRNA-1273, \\
respectively, \\
administered \\
through IM \\
between \\
$56-70$ years \\
age range
\end{tabular} & 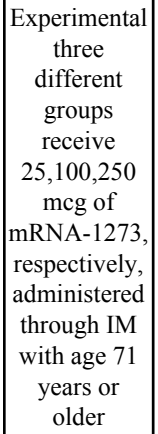 & 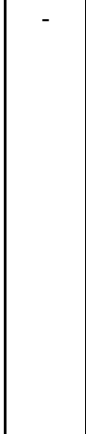 & $\begin{array}{c}\text { Frequency of solicited } \\
\text { local reactogenicity } \\
\text { adverse events (AEs) } \\
\text { [ Time Frame: Through } \\
7 \text { days post- } \\
\text { vaccination ]; } \\
\text { Frequency of any } \\
\text { medically-attended } \\
\text { adverse events } \\
\text { (MAAEs) } \\
\text { [ Time Frame: Day } 1 \text { to } \\
\text { Day 394 ] }\end{array}$ & $\begin{array}{l}\text { National } \\
\text { Institute of } \\
\text { Allergy and } \\
\text { Infectious } \\
\text { Diseases } \\
\text { (NIAID) }\end{array}$ \\
\hline
\end{tabular}

The data of recent clinical trials on vaccines is collected, separated and compiled from https://www.clinicaltrials.gov/ and http://www.chictr.org.cn/enindex.aspx

\subsection{Transfusion of Convalescent Plasma}

The administration of convalescent plasma to SARS-CoV2 infected patients shows recovery from the virus's etiology and pooled mortality rates as significantly decreased compared with or without placebo [64 - 66]. The health commissions of various backgrounds have asked recovered patients for donating their blood. Patients who received convalescent plasma reported a rapid recovery within 14 days, compared with other patients during the SARS CoV outbreak [67]. Table 6 shows the list of recent clinical trials of plasma therapies in patients with COVID-19.

\subsection{Vaccines}

The already revealed interaction among host receptors with coronavirus allows researchers to find a cure for nCoV 2019. In recent centuries, vaccination in severe diseases has been a significant defensive function. A clinic trial of six vaccines was carried out to test the efficacy of these vaccines, including mRNA1273(NCT042834461), S-protein adenoviral type 5 (NCT04313127), Chimpanzee adenoviral vector ChAdOx1 (NCT04324606), S-protein plasm encoding (NCT04336410), Lentiviral DCs modified (NCT04276896) and artificial antigen cells modified with lentiviral vector expression. The clinical trial without pre-clinical studies was concluded in a very short period because of the high and safe therapy potential of mRNA1279-COVID-19 (NCT04283461) encapsulated nanoparticles [68]. The safety profile of the mRNA vaccine is outstanding and has excellent immunological properties. mRNA vaccines are mostly induced by cellular and humoral immunity [69]. A list of recent clinical trials of vaccines in COVID-19 patients shown in Table 7 can be a game-changer for vaccine technologies.

\section{CONCLUSION: FUTURE ASPECTS}

Over the past two decades, coronavirus has shown worldwide health concerns. The disease is likely linked to hematological and respiratory problems. The spike protein of SARS-CoV-2 is more likely to reach the host compared to SARS-CoV's spike protein, which means the transfer rate in the SARS-CoV-2 is high. Asymptomatic patients also have a high transmission rate. The host immune response must be improved to fight against coronavirus. The intermediate reservoir of nCoV-2019 is still challenging for researchers. Coronaviruses are significantly attached to the ACE2 receptor of host organisms. The open reading frame of coronaviruses is responsible to distinguish between SARS-CoV-2 and SARS$\mathrm{CoV}$. Various clinical studies have started to identify potential therapies for eradicating this pandemic, and, until now, no effective nCoV-2019 drugs or vaccines are available. All drugs are based on the experience of SARS, MERS, and other strained viruses. Running clinical trials must be focused on quality data that can be used in possible prevention and treatments. In addition to medicines, techniques for respiratory support and modulation of immune status are highly required. Global resources with reasonable scientific justification are available for the planning of clinical trials. In recent clinical trials, the repurposing and repositioning of certain drugs have been processed. The repurposing of medicines has some barriers while repositioning clinical studies facilitate the discovery of new drugs. By this year, the way to find COVID-19 solutions should be through global cooperation with different clinical trial hospitals with a large number of patients. More work is required to find out exactly how this coronavirus is being approached. 


\section{LIST OF ABBREVIATIONS}

$\begin{array}{ll}\text { SARS-CoV } & =\text { Severe Acute Respiratory Syndrome Coronavirus } \\ \text { MERS-CoV } & =\text { Middle East Respiratory Syndromecoronavirus } \\ \text { nCoV } & =\text { novel Coronavirus } \\ \mathbf{S} & =\text { Spike protein } \\ \mathbf{E} & =\text { Envelope protein } \\ \mathbf{M} & =\text { Membrane protein } \\ \mathbf{N} & =\text { Nucleocapsid protein } \\ \text { ACE2 } & =\text { Angiotensin-Converting Enzyme } \\ \text { ORFs } & =\text { Open Reading Frames } \\ \text { UTR } & =\text { Untranslated region } \\ \text { RdRp } & =\text { RNA dependent RNA polymerase } \\ \text { nsp } & =\text { Non-structural protein }\end{array}$

\section{CONSENT FOR PUBLICATION}

Not applicable.

\section{FUNDING}

None.

\section{CONFLICT OF INTEREST}

The author confirm that this article content has no conflicts of interest.

\section{ACKNOWLEDGEMENTS}

The authors express their gratitude to Chairman, Mr. Parveen Garg and Director, Dr.G.D.Gupta, ISF College of Pharmacy, Moga (Punjab), India, for their excellent vision and support.

\section{REFERENCES}

[1] Chen Y, Liu Q, Guo D. Emerging coronaviruses: Genome structure, replication, and pathogenesis. J Med Virol 2020; 92(4): 418-23. [http://dx.doi.org/10.1002/jmv.25681] [PMID: 31967327]

[2] Cui J, Li F, Shi ZL. Origin and evolution of pathogenic coronaviruses. Nat Rev Microbiol 2019; 17(3): 181-92. [http://dx.doi.org/10.1038/s41579-018-0118-9] [PMID: 30531947]

[3] World Health Organisation. 2020 .https://www.who.int/csr/sars/ en/WHOconsensus.pdf

[4] World Health Organisation. 2020.https://www.who.int/emergencies/ diseases/novel-coronavirus-2019/situation-reports

[5] Chan-Yeung M, Xu RH. SARS: epidemiology. Respirology 2003; 8(Suppl.): S9-S14.

[http://dx.doi.org/10.1046/j.1440-1843.2003.00518.x] [PMID: 15018127]

[6] Xu P, Zhou Q, Xu J. Mechanism of thrombocytopenia in COVID-19 patients. Ann Hematol 2020; 99(6): 1205-8. [http://dx.doi.org/10.1007/s00277-020-04019-0] [PMID: 32296910]

[7] Rahman A, Sarkar A. Risk factors for fatal middle east respiratory syndrome coronavirus infections in Saudi Arabia: analysis of the WHO Line List, 2013-2018. Am J Public Health 2019; 109(9): 1288-93.

[http://dx.doi.org/10.2105/AJPH.2019.305186] [PMID: 31318592]

[8] Shereen MA, Khan S, Kazmi A, Bashir N, Siddique R. COVID-19 infection: Origin, transmission, and characteristics of human coronaviruses. J Adv Res 2020; 24: 91-8.

[http://dx.doi.org/10.1016/j.jare.2020.03.005] [PMID: 32257431]

[9] Wang C, Horby PW, Hayden FG, Gao GF. A novel coronavirus outbreak of global health concern. Lancet 2020; 395(10223): 470-3. [http://dx.doi.org/10.1016/S0140-6736(20)30185-9] [PMID: 31986257]

[10] Parry J. China coronavirus: cases surge as official admits human to human transmission. BMJ 2020; 368: m236.

[http://dx.doi.org/10.1136/bmj.m236] [PMID: 31959587]

[11] Hui DS, I Azhar E, Madani TA, et al. The continuing 2019-nCoV epidemic threat of novel coronaviruses to global health - The latest 2019 novel coronavirus outbreak in Wuhan, China. Int J Infect Dis 2020; 91: 264-6.

[http://dx.doi.org/10.1016/j.ijid.2020.01.009] [PMID: 31953166]

[12] Gu J, Korteweg C. Pathology and pathogenesis of severe acute respiratory syndrome. Am J Pathol 2007; 170(4): 1136-47. [http://dx.doi.org/10.2353/ajpath.2007.061088] [PMID: 17392154]

[13] Memish ZA, Zumla AI, Al-Hakeem RF, Al-Rabeeah AA, Stephens GM. Family cluster of Middle East respiratory syndrome coronavirus infections. N Engl J Med 2013; 368(26): 2487-94.

[http://dx.doi.org/10.1056/NEJMoa1303729] [PMID: 23718156]

[14] Paden CR, Yusof MFBM, Al Hammadi ZM, et al. Zoonotic origin and transmission of Middle East respiratory syndrome coronavirus in the UAE. Zoonoses Public Health 2018; 65(3): 322-33.

[http://dx.doi.org/10.1111/zph.12435] [PMID: 29239118]

[15] Azhar EI, El-Kafrawy SA, Farraj SA, et al. Evidence for camel-tohuman transmission of MERS coronavirus. N Engl J Med 2014; 370(26): 2499-505.

[http://dx.doi.org/10.1056/NEJMoa1401505] [PMID: 24896817]

[16] Bolles M, Donaldson E, Baric R. SARS-CoV and emergent coronaviruses: Viral determinants of interspecies transmission. Curr Opin Virol 2011; 1(6): 624-34.

[http://dx.doi.org/10.1016/j.coviro.2011.10.012] [PMID: 22180768]

[17] World Health Organisation. 2020 .https://www.who.int/emergencies/mers-cov/en/

[18] World Health Organisation. 2020 .https://www.who.int/ith/diseases/ sars/en/

[19] World Health Organisation. 2020 .https://www.who.int/emergencies/diseases/novel-coronavirus-2019

[20] Lu R, Zhao X, Li J, et al. Genomic characterisation and epidemiology of 2019 novel coronavirus: Implications for virus origins and receptor binding. Lancet 2020; 395(10224): 565-74.

[http://dx.doi.org/10.1016/S0140-6736(20)30251-8] [PMID: 32007145]

[21] Song W, Wang Y, Wang N, et al. Identification of residues on human receptor DPP4 critical for MERS-CoV binding and entry. Virology 2014; 471-473: 49-53.

[http://dx.doi.org/10.1016/j.virol.2014.10.006] [PMID: 25461530]

[22] Chan JF, Choi GK, Tsang AK, et al. Development and evaluation of novel real-time reverse transcription-PCR assays with locked nucleic acid probes targeting leader sequences of human-pathogenic coronaviruses. J Clin Microbiol 2015; 53(8): 2722-6.

[http://dx.doi.org/10.1128/JCM.01224-15] [PMID: 26019210]

[23] Bhadra S, Jiang YS, Kumar MR, Johnson RF, Hensley LE, Ellington AD. Real-time sequence-validated loop-mediated isothermal amplification assays for detection of Middle East respiratory syndrome coronavirus (MERS-CoV). PLoS One 2015; 10(4)e0123126 [http://dx.doi.org/10.1371/journal.pone.0123126] [PMID: 25856093]

[24] Lee SH, Baek YH, Kim YH, Choi YK, Song MS, Ahn JY. One-pot reverse transcriptional loop-mediated isothermal amplification (RTLAMP) for detecting MERS-CoV. Front Microbiol 2017; 7: 2166. [http://dx.doi.org/10.3389/fmicb.2016.02166] [PMID: 28119682]

[25] Guo YR, Cao QD, Hong ZS, et al. The origin, transmission and clinical therapies on coronavirus disease 2019 (COVID-19) outbreakan update on the status. Mil Med Res 2020; 7(1): 1-0.

[http://dx.doi.org/10.1186/s40779-020-00240-0] [PMID: 31928528]

[26] Han Y, Yang H. The transmission and diagnosis of 2019 novel coronavirus infection disease (COVID-19): A Chinese perspective. J Med Virol 2020; 92(6): 639-44.

[http://dx.doi.org/10.1002/jmv.25749] [PMID: 32141619]

[27] van Boheemen S, de Graaf M, Lauber C, et al. Genomic characterization of a newly discovered coronavirus associated with acute respiratory distress syndrome in humans. MBio 2012; 3(6)e00473-12 [http://dx.doi.org/10.1128/mBio.00473-12] [PMID: 23170002]

[28] Perlman S, Netland J. Coronaviruses post-SARS: Update on replication and pathogenesis. Nat Rev Microbiol 2009; 7(6): 439-50. [http://dx.doi.org/10.1038/nrmicro2147] [PMID: 19430490]

[29] Glowacka I, Bertram S, Müller MA, et al. Evidence that TMPRSS2 activates the severe acute respiratory syndrome coronavirus spike protein for membrane fusion and reduces viral control by the humoral immune response. J Virol 2011; 85(9): 4122-34. [http://dx.doi.org/10.1128/JVI.02232-10] [PMID: 21325420]

[30] Gallagher TM, Buchmeier MJ. Coronavirus spike proteins in viral entry and pathogenesis. Virology 2001; 279(2): 371-4. 
[http://dx.doi.org/10.1006/viro.2000.0757] [PMID: 11162792]

[31] Wu A, Peng Y, Huang B, et al. Genome composition and divergence of the novel coronavirus (2019-nCoV) originating in China. Cell Host Microbe 2020; 27(3): 325-8

[http://dx.doi.org/10.1016/j.chom.2020.02.001] [PMID: 32035028]

[32] Zhou P, Yang XL, Wang XG, et al. A pneumonia outbreak associated with a new coronavirus of probable bat origin. nature 2020; 579(7798): 270-3

[33] Xu X, Chen P, Wang J, et al. Evolution of the novel coronavirus from the ongoing Wuhan outbreak and modeling of its spike protein for risk of human transmission. Sci China Life Sci 2020; 63(3): 457-60. [http://dx.doi.org/10.1007/s11427-020-1637-5] [PMID: 32009228]

[34] Wan Y, Shang J, Graham R, Baric RS, Li F. Receptor recognition by the novel coronavirus from Wuhan: An analysis based on decade-long structural studies of SARS coronavirus. J Virol 2020; 94(7)e00127-20 [http://dx.doi.org/10.1128/JVI.00127-20] [PMID: 31996437]

[35] Zhang H, Penninger JM, Li Y, Zhong N, Slutsky AS. Angiotensinconverting enzyme 2 (ACE2) as a SARS-CoV-2 receptor: molecular mechanisms and potential therapeutic target. Intensive Care Med 2020; 46(4): 586-90.

[http://dx.doi.org/10.1007/s00134-020-05985-9] [PMID: 32125455]

[36] Song $\mathrm{Z}, \mathrm{Xu} \mathrm{Y}$, Bao L, et al. From SARS to MERS, thrusting coronaviruses into the spotlight. Viruses 2019; 11(1): 59

[http://dx.doi.org/10.3390/v11010059] [PMID: 30646565]

[37] Mehta P, McAuley DF, Brown M, Sanchez E, Tattersall RS, Manson JJ. COVID-19: consider cytokine storm syndromes and immunosuppression. Lancet 2020; 395(10229): 1033-4. [http://dx.doi.org/10.1016/S0140-6736(20)30628-0]

[PMID: 32192578]

[38] Hassan SS, Choudhury PP, Basu P, Jana SS. Molecular conservation and differential mutation on ORF3a gene in Indian SARS-CoV2 genomes. Genomics 2020; 112(5): 3226-37.

[http://dx.doi.org/10.1016/j.ygeno.2020.06.016] [PMID: 32540495]

[39] Tong TR. Drug targets in severe acute respiratory syndrome (SARS) virus and other coronavirus infections. Infectious Disorders-Drug Targets (Formerly Current Drug Targets-Infectious Disorders) 2009; 9(2): 223-45.

[40] Naqvi AA, Fatima K, Mohammad T, et al. Insights into SARS-CoV-2 genome, structure, evolution, pathogenesis and therapies: Structural genomics approach. Biochimica et Biophysica Acta (BBA)-Molecular Basis of Disease 2020; 165878.

[41] Liu DX, Fung TS, Chong KK, Shukla A, Hilgenfeld R. Accessory proteins of SARS-CoV and other coronaviruses. Antiviral Res 2014; 109: 97-109.

[http://dx.doi.org/10.1016/j.antiviral.2014.06.013] [PMID: 24995382]

[42] Angeletti S, Benvenuto D, Bianchi M, Giovanetti M, Pascarella S, Ciccozzi M. COVID-2019: The role of the nsp2 and nsp3 in its pathogenesis. J Med Virol 2020; 92(6): 584-8.

[http://dx.doi.org/10.1002/jmv.25719] [PMID: 32083328]

[43] Li B, Si HR, Zhu Y, et al. Discovery of bat coronaviruses through surveillance and probe capture-based next-generation sequencing. MSphere 2020; 5(1): e00807-19.

[http://dx.doi.org/10.1128/mSphere.00807-19] [PMID: 31996413]

[44] Ceraolo C, Giorgi FM. Genomic variance of the 2019-nCoV coronavirus. J Med Virol 2020; 92(5): 522-8.

[http://dx.doi.org/10.1002/jmv.25700] [PMID: 32027036]

[45] Zhou Y, Yang Y, Huang J, Jiang S, Du L. Advances in MERS-CoV vaccines and therapeutics based on the receptor-binding domain. Viruses 2019; 11(1): 60.

[http://dx.doi.org/10.3390/v11010060] [PMID: 30646569]

[46] Ng CS, Kasumba DM, Fujita T, Luo H. Spatio-temporal characterization of the antiviral activity of the XRN1-DCP1/2 aggregation against cytoplasmic RNA viruses to prevent cell death. Cell Death Differ 2020; 27(8): 2363-82

[http://dx.doi.org/10.1038/s41418-020-0509-0] [PMID: 32034313]

[47] Cao B, Wang Y, Wen D, et al. A trial of lopinavir-ritonavir in adults hospitalized with severe COVID-19. N Engl J Med 2020; 382(19): 1787-99.

[http://dx.doi.org/10.1056/NEJMoa2001282] [PMID: 32187464]

[48] Sheahan TP, Sims AC, Leist SR, et al. Comparative therapeutic efficacy of remdesivir and combination lopinavir, ritonavir, and interferon beta against MERS-CoV. Nat Commun 2020; 11(1): 222. [http://dx.doi.org/10.1038/s41467-019-13940-6] [PMID: 31924756]

[49] Mulangu S, Dodd LE, Davey RT Jr, et al. A randomized, controlled trial of Ebola virus disease therapeutics. N Engl J Med 2019; 381(24): 2293-303.

[http://dx.doi.org/10.1056/NEJMoa1910993] [PMID: 31774950]
[50] Tchesnokov EP, Feng JY, Porter DP, Götte M. Mechanism of inhibition of Ebola virus RNA-dependent RNA polymerase by remdesivir. Viruses 2019; 11(4): 326.

[http://dx.doi.org/10.3390/v11040326] [PMID: 30987343]

[51] Vincent MJ, Bergeron E, Benjannet S, et al. Chloroquine is a potent inhibitor of SARS coronavirus infection and spread. Virol J 2005; 2(1): 69 .

[http://dx.doi.org/10.1186/1743-422X-2-69] [PMID: 16115318]

[52] Chua J, Senft JL, Lockett SJ, et al. $\mathrm{pH}$ alkalinization by chloroquine suppresses pathogenic Burkholderia type 6 secretion system 1 and multinucleated giant cells. Infect Immun 2016; 85(1): e00586-16.

[http://dx.doi.org/10.1128/IAI.00586-16] [PMID: 27799332]

[53] Delvecchio R, Higa LM, Pezzuto P, et al. Chloroquine, an endocytosis blocking agent, inhibits Zika virus infection in different cell models. Viruses 2016; 8(12): 322. [http://dx.doi.org/10.3390/v8120322] [PMID: 27916837]

[54] Xue J, Moyer A, Peng B, Wu J, Hannafon BN, Ding WQ. Chloroquine is a zinc ionophore. PLoS One 2014; 9(10): e109180. [http://dx.doi.org/10.1371/journal.pone.0109180] [PMID: 25271834]

[55] Te Velthuis AJ, Van den Worm SH, Sims AC, Baric RS, Snijder EJ, van Hemert MJ. $\mathrm{Zn}^{(2+)}$ inhibits coronavirus and arterivirus RNA polymerase activity in vitro and zinc ionophores block the replication of these viruses in cell culture. PLoS Pathog 2010 Nov 4; 6(11): e1001176.

[http://dx.doi.org/10.1371/journal.ppat.1001176] [PMID: 21079686]

[56] Liu J, Cao R, Xu M, et al. Hydroxychloroquine, a less toxic derivative of chloroquine, is effective in inhibiting SARS-CoV-2 infection in vitro. Cell Discov 2020; 6(1): 1-4.

[http://dx.doi.org/10.1038/s41421-019-0132-8] [PMID: 33402673]

[57] Yao X, Ye F, Zhang M, et al. In vitro antiviral activity and projection of optimized dosing design of hydroxychloroquine for the treatment of severe acute respiratory syndrome coronavirus 2 (SARS-CoV-2). Clin Infect Dis 2020; 71(15): 732-9.

[http://dx.doi.org/10.1093/cid/ciaa237] [PMID: 32150618]

[58] Caly L, Druce JD, Catton MG, Jans DA, Wagstaff KM. The FDAapproved drug ivermectin inhibits the replication of SARS-CoV-2 in vitro. Antiviral Res 2020; 178104787

[http://dx.doi.org/10.1016/j.antiviral.2020.104787] [PMID: 32251768]

[59] Russell B, Moss C, Rigg A, Van Hemelrijck M. COVID-19 and treatment with NSAIDs and corticosteroids: Should we be limiting their use in the clinical setting?. ecancermedicalscience $2020 ; 14$

[60] Ramamoorthy S, Cidlowski JA. Corticosteroids: Mechanisms of action in health and disease. Rheum Dis Clin North Am 2016; 42(1): 15-31, vii.

[http://dx.doi.org/10.1016/j.rdc.2015.08.002] [PMID: 26611548]

[61] Zhang X, Alekseev K, Jung K, Vlasova A, Hadya N, Saif LJ. Cytokine responses in porcine respiratory coronavirus-infected pigs treated with corticosteroids as a model for severe acute respiratory syndrome. J Virol 2008 May; 82(9): 4420-8.

[http://dx.doi.org/10.1128/JVI.02190-07] [PMID: 18287230]

[62] Wang C, Li W, Drabek D, et al. A human monoclonal antibody blocking SARS-CoV-2 infection. Nat Commun 2020; 11(1): 1-6. [PMID: 31911652]

[63] Tian X, Li C, Huang A, et al. Potent binding of 2019 novel coronavirus spike protein by a SARS coronavirus-specific human monoclonal antibody. Emerg Microbes Infect 2020; 9(1): 382-5. [http://dx.doi.org/10.1080/22221751.2020.1729069] 32065055]

[64] Teixeira da Silva JA. Convalescent plasma: A possible treatment of COVID-19 in India. Med J Armed Forces India 2020; 76(2): 236-7. [http://dx.doi.org/10.1016/j.mjafi.2020.04.006] [PMID: 32296259]

[65] Rajendran K, Krishnasamy N, Rangarajan J, Rathinam J, Natarajan M, Ramachandran A. Convalescent plasma transfusion for the treatment of COVID-19: Systematic review. J Med Virol 2020; 92(9): 1475-83. [http://dx.doi.org/10.1002/jmv.25961] [PMID: 32356910]

[66] Mair-Jenkins J, Saavedra-Campos M, Baillie JK, et al. The effectiveness of convalescent plasma and hyperimmune immunoglobulin for the treatment of severe acute respiratory infections of viral etiology: a systematic review and exploratory meta-analysis. J Infect Dis 2015; 211(1): 80-90.

[http://dx.doi.org/10.1093/infdis/jiu396] [PMID: 25030060]

[67] Sheridan C. Convalescent serum lines up as first-choice treatment for coronavirus. Nat Biotechnol 2020; 38(6): 655-8. [http://dx.doi.org/10.1038/d41587-020-00011-1] [PMID: 32358594]

[68] Kim YC, Dema B, Reyes-Sandoval A. COVID-19 vaccines: Breaking record times to first-in-human trials. npj. Vaccines (Basel) 2020; 5(1): $1-3$. 


\section{(C) 2021 Kundu \& Singh.}

This is an open access article distributed under the terms of the Creative Commons Attribution 4.0 International Public License (CC-BY 4.0), a copy of which is available at: https://creativecommons.org/licenses/by/4.0/legalcode. This license permits unrestricted use, distribution, and reproduction in any medium, provided the original author and source are credited. 